\begin{tabular}{|c|c|c|c|c|c|c|}
\hline \multirow{4}{*}{ Impact Factor: } & ISRA (India) & $=3.117$ & SIS (USA) & $=0.912$ & ICV (Poland) & $=6.630$ \\
\hline & ISI (Dubai, UAE & $=0.829$ & РИНЦ (Russia) & $=0.156$ & PIF (India) & $=1.940$ \\
\hline & GIF (Australia) & $=0.564$ & ESJI (KZ) & $=8.716$ & IBI (India) & $=4.260$ \\
\hline & JIF & $=1.500$ & SJIF (Morocco) & $=5.667$ & OAJI (USA) & $=0.350$ \\
\hline
\end{tabular}

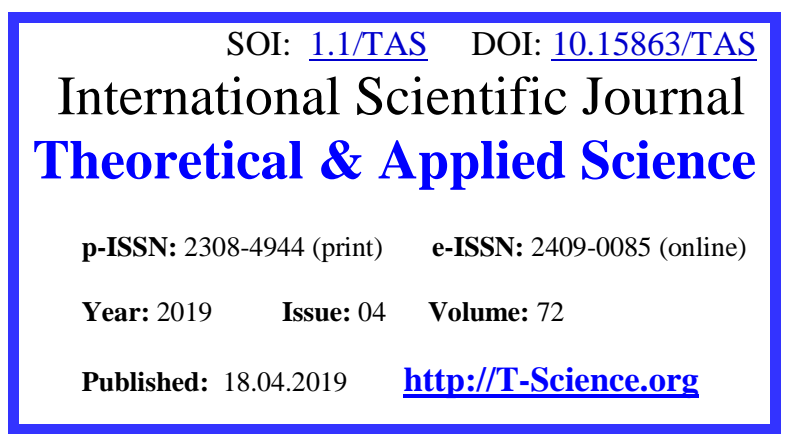

UDC 685.39:317.61.

SECTION 31: Economic

researches,

finance, innovations,

risk management.
QR - Issue

QR - Article
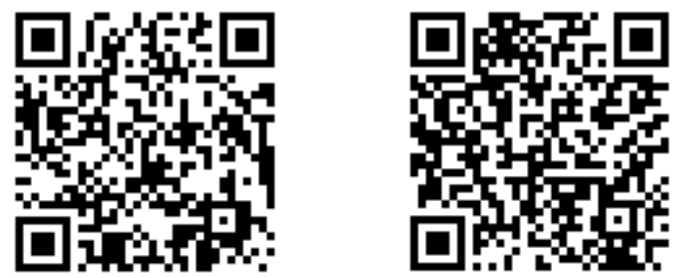

Artur Alexandrovich Blagorodov bachelor Institute of Entrepreneurship and Service sector (branch) DSTU, g. Shakhty

Dmitri Olegovich Bordukh bachelor Institute of Entrepreneurship and Service sector (branch) DSTU, g. Shakhty

Anna Vyacheslavovna Golovko undergraduate, Institute of Entrepreneurship and Service sector (branch) DSTU, g. Shakhty

Vladimir Timofeevich Prohorov

Doctor of technical sciences, professor, Institute of Entrepreneurship and Service sector (branch) DSTU, g. Shakhty

Sergey Petrovich Petrosov Doctor of technical sciences, professor, Institute of Entrepreneurship and Service sector (branch) DSTU, g. Shakhty

Natalia Vassilievna Tikhonova Kazan national research technological University

(Kazan, Republic of Tatarstan)

\title{
ON THE UNION OF PARTICIPATORY MANAGEMENT TEAMS OF ENTERPRISES AND THE IMPLEMENTATION OF THE PROVISIONS OF THE FEDERAL LAW "ON TECHNICAL REGULATION" FOR MAKING THEM COMPETITIVE AND MARKETABLE PRODUCTS
}

Abstract: the authors argue that the management of manufacturing, including standardization, should be thoroughly prepared with the maximum reliance on the reserves of the professional culture of specialists, but the dynamics of the control of the running production, it is desirable to instruct the technical programs and tools. So everything will be more reliable. But technical management has its weaknesses. Among them: a high level of energy dependence, computer security is not absolute, the requirements for the personal abilities of specialists in terms of personal and team responsibility increased, sometimes up to exclusive. Problems at work, as a rule, are created by people, but it is in the absence of qualified specialists that the most serious problems arise. Technical standardized management is not a panacea.

Key words: QMS, certification, import substitution, demanded, conformity assessment, standardization, audit , demand, defective products, Pareto chart, quality policy and objectives, effectiveness, efficiency, responsibility.

Language: Russian

Citation: Blagorodov, A. A., Bordukh, D. O., Golovko, A. V., Prohorov, V. T., Petrosov, S. P., \& Tikhonova, N. V. (2019). On the union of participatory management teams of enterprises and the implementation of the provisions of the federal law "on technical regulation" for making them competitive and marketable products. ISJ Theoretical \& Applied Science, 04 (72), 228-262.

Soi: http://s-o-i.org/1.1/TAS-04-72-27 Doi: crossef https://dx.doi.org/10.15863/TAS 


\begin{tabular}{|c|c|c|c|c|c|c|}
\hline \multirow{4}{*}{ Impact Factor: } & ISRA (India) & $=3.117$ & SIS (USA) & $=0.912$ & ICV (Poland) & $=6.630$ \\
\hline & ISI (Dubai, UAE & $=0.829$ & РИНЦ (Russia & $=\mathbf{0 . 1 5 6}$ & PIF (India) & $=1.940$ \\
\hline & GIF (Australia) & $=0.564$ & ESJI (KZ) & $=8.716$ & IBI (India) & $=4.260$ \\
\hline & JIF & $=1.500$ & SJIF (Morocco & $=\mathbf{5 . 6 6 7}$ & OAJI (USA) & $=0.350$ \\
\hline
\end{tabular}

\section{О СОЮЗЕ ПАРТИСИПАТИВНОГО УПРАВЛЕНИЯ КОЛЛЕКТИВАМИ ПРЕДПРИЯТИЙ И РЕАЛИЗАЦИИ ПОЛОЖЕНИЙ ФЗ « О ТЕХНИЧЕСКОМ РЕГУЛИРОВАНИИ» ДЛЯ ИЗГОТОВЛЕНИЯ ИМИ КОНКУРЕНТОСПОСОБНОЙ И ВОСТРЕБОВАННОЙ ПРОДУКЦИИ}

Аннотация: авторы утверждают, что управление производством, включая стандартизацию, нужно тщңательно готовить с максимальной опорой на резервы профессиональной культурь специиалистов, но динамику управления запущенным производством желательно поручить техническим программам и средствам. Так все будет надежнее. Но у технического управление есть свои слабые места. Среди них: высокий уровень энергетической зависимости, компьютерная безопасность не абсолютна, требования к личностным способностям специалистов в условиях персональной и командной ответственности повыленные, временами вплоть до эксклюзивных. Проблемы на производстве, как правило, создают люди, но именно в отсутствии квалифицированных специалистов возникают самые серьезные проблемы. Техническое стандартизированное управление - не панацея.

Ключевые слова: СМК, сертификачия, импортозамещение, востребованное, подтверждение соответствия, стандартизация, аудит, спрос, бракованная продукция, диаграмма Парето, политика и цели качества, результативность , эффективность, ответственность.

\section{Введение}

В настоящее время на предприятиях большое значение уделяют мотивации сотрудников, так как в зависимости от того, насколько сотрудник мотивирован, будут видны и результаты его деятельности. Основной задачей менеджеров становится полное задействование в работе всего потенциала сотрудников. Причем менеджеры понимают, что материальное стимулирование не повышает лояльность и приверженность предприятию. Партисипативное управление решает эту проблему.

Суть такого управления состоит в том, что при нем сотрудники предприятия включаются в процесс управления, участвуют в деятельности предприятия, принимают решения по ряду вопросов. Причем, если сотрудник предприятия имеет право голоса, принимает участие в деятельности предприятия, получая за это вознаграждение, тогда он будет работать более качественно и производительно. Сотрудник, с мнением которого считаются, идеи которого внедряются, будет лучше относиться к месту своей работы и будет работать с полной отдачей.

При партисипативном управлении сотрудники могут обговаривать с руководителем цели и задачи, которые ему будет необходимо выполнить. Сотрудники предприятия могут сформировать рабочие группы из тех сотрудников, с которыми им было бы приятно и комфортно работать. Помимо этого сотрудники предприятия могут выдвигать свои идеи и предложения по поводу усовершенствования работы предприятия в целом. Причем за выдвижение идей должно идти и вознаграждение.

Партисипативное управление имеет ряд преимуществ. Участие в управлении сотрудников приводит к повышению качества принимаемых решений, поскольку работники могут обладать той информацией, которая неизвестна руководителю. При таком управлении сотрудники могут проявить в полной мере себя, показать свои знания и умения, а также почувствовать свою значимость на предприятии, таким образом повышая мотивацию. В основе мотивации обычно присутствуют не только личные достижения сотрудника, но и общий результат работы предприятия. Объединение сотрудников по рабочим группам наилучшим образом может отразиться на корпоративном духе предприятия.

\section{Основная часть}

Производитель традиционно озабочен думою, как обеспечить предельно возможное соответствие товарной продукции востребованным образцам. В условиях массового производства такая проблема достаточно затратна, так как требует организации специальной развернутой службы, а главное, - где взять значительное количество квалифицированных работников. Японцы, столкнувшись с проблемой обеспечения производства квалифицированными исполнителями, вынуждены были решать её весьма своеобразно - на свои предприятия, расположенные в соседних государствах: Малайзии, Таиланда, Сингапура, Индонезии, поставляли самую передовую технику, чтобы свести к минимуму ручной труд. Не все готовы последовать примеру Японии [1].

Линейное развитие экономики наверняка привело бы в тупик - массовое производство со временем стало бы крайне затратным. Никакой инновационный технологический процесс, основанный на использовании многофункционального и универсального оборудования, не решил бы всех проблем в рамках цифрового производства. Во-первых, сокращение персонала вызвало бы рост безработицы со всеми вытекающими социальными негативами, вовторых, всё равно нужны были бы квалифицированные работники в большом количестве. 


\begin{tabular}{|c|c|c|c|c|c|c|}
\hline \multirow{4}{*}{ Impact Factor: } & ISRA (India) & $=3.117$ & SIS (USA) & $=0.912$ & ICV (Poland) & $=6.630$ \\
\hline & ISI (Dubai, UAE & $=0.829$ & РИНЦ (Russia & $=0.156$ & PIF (India) & $=1.940$ \\
\hline & GIF (Australia) & $=0.564$ & ESJI (KZ) & $=8.716$ & IBI (India) & $=4.260$ \\
\hline & JIF & $=1.500$ & SJIF (Morocco & $=\mathbf{5 . 6 6 7}$ & OAJI (USA) & $=0.350$ \\
\hline
\end{tabular}

Спасение пришло от нелинейности, заложенной в диалектику прогресса. Экономика массового производства отработала свой ресурс и, подобно очередной ступени ракеты, потеряла необходимость существования. Экономическая парадигма сменилась. Нерациональное в различных аспектах - экологическом, гуманитарном, экономическом, массовое производство уступило место «рачительной экономике» (lean production). Производство принципиально меняет цель. Традиционная задача изготовления большого числа однотипных изделий, отвечающих требованиям нормативной документации, из которых потребителю предлагается выбрать наиболее подходящие, заменяется задачей изготовления именно такого изделия, какое нужно данному потребителю и именно в требуемом объёме и в определённое время.

«Рачительная» (щадящая) экономика акцентирует внимание производителя на состоянии потребительского настроения. Производителю необходимо изучать спрос, искать свою нишу в потребительском спросе, «воспитывать» с помощью рекламы, просветительской работы, организации сервисного обслуживания своего покупателя.

Новая экономическая философия сближает производителя и потребителя, подчеркивает диалектичность их взаимоотношений - они противоположности, но такие, которые существуют только в единстве. Изначально производитель и потребитель вообще были в одном лице. Разделение труда и повышение его производительности физически отделили одного от другого, однако суть отношений не изменилась. Рынок их противопоставил, усложнив систему пространственных отношений посредническими, транспортными и прочими инструментами. Задача, объединяющая производителя и потребителя, заключается в том, чтобы не упускать друг друга из вида, расчищать рыночные надстройки, делать себя непосредственными финансовыми партнерами, снижая финансовую нагрузку на производство.

Вместе с тем, производитель и потребитель в системе рыночных отношений, порождённых товарной экономикой, противостоят один другому, поэтому их понимание качества производства, товара совпадают частично, что также важно учитывать, обустраивая присутствие на рынке, надеясь закрепиться там на всю оставшуюся жизнь.

Общими признаками качества товара для производителя и потребителя будут его полезность, удобность, гигиеничность, эргономичность, устойчивость к деформации, простота в обращении, соответствие моде. Потребителя, в отличие от производителя, мало интересует качество производства товара, хотя, «раскрученный», то есть просвещенный потребитель не должен, по логике изменения вещей, совсем игнорировать технологию, организацию производства. Связь качества изделия и качества производства носит причинноследственный характер, и это вполне доступно дилетантскому пониманию.[2]

Со своей стороны производитель рискует оказаться не у дел, если недооценит специфику представлений о качестве товара потребителей. Э. Деминг- автор классификации «смертельных болезней» для производителя - среди семи смертей назвал под №1 «ориентирование производства на такие товары, которые не пользуются спросом на рынке», то есть не востребованы потребителем; №2 - «акцент на краткосрочные прибыли и сиюминутные выгоды». В обоих случаях производитель допускает одну и ту же методологическую ошибку - он изымает свою деятельность из системы взаимоотношений, «свой участок» делает всеобщим, за что и расплачивается полной мерой.

Представление потребителя о качестве товара потребления менее объективно, в сравнении с пониманием производителя. Добросовестный производитель, принимая профессиональные обязательства, привлекает научные знания, независимые экспертизы и т.п. Потребитель, в противоположность профессионалу-производителю, является в общей массе «любителем». Его взгляды на качество товара, упрощённо говоря, обывательские, основываются не на научных знаниях, а на здравом смысле. В них преобладает прагматический подход, субъективированная оценка. Теоретически, правым всегда должен быть производитель; практически - тогда не было бы нормального рынка, поэтому всем известно противоположное утверждение: покупатель всегда прав.

Доминирование прагматического подхода к качеству товара у потребителя - своего рода издержка в отношениях основных рыночных субъектов. С этим приходится мириться, иначе, по-видимому, невозможно выстроить системообразующее звено рыночной практики. Потребитель, в качестве покупателя, ограничен платёжеспособностью. У производителя есть определённые теоретические ресурсы, например, увеличить объём продаж, оборотные средства, сократить расходы и т.д. Потребитель-покупатель реальных резервов не имеет- кредиты только увеличат его расходы, причём в России очень существенно. Исходя из своей ситуации, потребитель на качество товара смотрит через прицел количества рублей, выставленного продавцом как эквивалент качества. К сказанному добавим тот скепсис, который пробуждает в 


\begin{tabular}{|c|c|c|c|c|c|c|}
\hline \multirow{4}{*}{ Impact Factor: } & ISRA (India) & $=3.117$ & SIS (USA) & $=0.912$ & ICV (Poland) & $=6.630$ \\
\hline & ISI (Dubai, UAE & $=0.829$ & РИНЦ (Russia) & $=0.156$ & PIF (India) & $=1.940$ \\
\hline & GIF (Australia) & $=0.564$ & ESJI (KZ) & $=8.716$ & IBI (India) & $=4.260$ \\
\hline & JIF & $=1.500$ & SJIF (Morocco & $=5.667$ & OAJI (USA) & $=0.350$ \\
\hline
\end{tabular}

сознании покупателя назойливое повторение: «цена соответствует качеству». Цена может быть эквивалентна качеству только в частном случае. На рынке кормится свора посредников.

«Качество» и «цена»- опорные понятия и для производителя и для потребителя, но вплетены в системные соображения они поразному - в зависимости от противоположности рыночного положения. Каждый из субъектов измеряет качество товара, исходя из собственного статуса.

Третий субъект отношений производителя и потребителя, и еще один «оценщик» качества товара - это рынок, являющийся инструментом регулирования отношений производителя и потребителя. Роль рынка исторически укреплялась по мере развития национальных экономик, создания транснациональных компаний. Рынок из эпизодического, ограниченного во времени инструмента, сделался вполне самостоятельным экономическим явлением. Разрастание рынка сопровождалось его структурной эволюцией, он выстроился в итоге в сложную пирамиду непосредственного, опосредованного участия; розничная торговля достроилась оптовой; сделки из настоящего времени ушли в будущее. На рынке обозначился лидер - рынок финансовых операций, что надо рассматривать как симптом, ибо финансовый рынок, по определению, отдалён от предмета и качество здесь представлено обобщенно, условно.[3]

«Качество товара», с точки зрения рынка, это признак ликвидности товара. Товар не залеживается, следовательно, искомое качество достигнуто. Рынку нет дела до того, удовлетворяет ли действительно качество товара потребителя. На рынке «король» не покупатель, а продавец и критерий качества - время реализации товара. Что будет потом? - продавца не очень волнует. Вот почему распространена такая «смертельная болезнь», как стремление к сиюминутному результату. Тем не менее, «рыночная теория» качества имеет место быть и с ней необходимо считаться при определении экономической политики.

Производство, потребление и рынок, оказавшийся субъектом их отношений культурные феномены, их историческая конкретность обусловлена временем, национальными и региональными особенностями развития. Словосочетания «культура производства» и «культура потребления» давно и прочно вписались в профессиональную лексику, что не скажешь о «культуре рынка». Различие объяснить не представляет труда. Производство и современное потребление базируются на научных знаниях, отражающих объективный порядок вещей, в них несложно проследить влияние культурных традиций.

История рынка не столь велика и отношение к рынку несколько иное в культуре. Рынок XX и нового столетия бесспорно вобрал в себя элементы культуры, однако оказался той самой деятельностью, которой не присущи фундаментальные культурные ценности. Девиз российских купцов: «Наша цель - прибыль, но честь выше!» прижился благодаря заложенному и культурно оформленному лукавству. Честные и совестливые продавцы на рынке никогда не задерживались - не их место. Если причислить искусство обманывать к совокупности культурных феноменов, то рынок является формой реальности массового культурно оформленного обмана. Обманывают всех, всегда и по-всякому. И в обмане на рынке искусства не меньше, чем в театре, где тоже, по-своему, обманывают.

Субъективированный, с неустойчивой, разнонаправленной динамикой движения, рынок слабо предсказуем. Те попытки, которые предпринимаются в прогнозировании поведения рынка, малопродуктивны именно по причине недостаточности объективных показателей системного вида. Так что резервы рынка, как области управления реальным качеством, невелики, тем более в отсутствии желания государства активно вмешиваться в архитектонику рыночных отношений.

У конкретного предприятия (лучше объединения, группы предприятий) перспективы продвижения товарной продукции на рынок связаны с разработкой ресурсов понимания качества в координатах производства - искать качественный компромисс и воспитанием своего потребителя.

Европейским и североамериканским производителям проще обустраиваться на рынке со своими товарами. Накоплен в течение двухтрех столетий опыт общения с потребителем, потребитель разобрался с производителями, нашел «своих» по интересам и карману; рынок сбалансировался, приспособился к требованиям законодательства; государство не прессингует рынок, производителя и покупателя, но там, где присутствует, делает это жёстко. С коррупцией, наездами, монопольными притязаниями не покончено, однако борьба ведётся реальная, а не декоративная, бутафорская, что существенно облегчает доступность рынка, унифицирует условия конкуренции.

Среди главных проблем европейских теоретиков и практиков удовлетворённость качеством товаров потребителя. Проблема, в схематичном выражении, простая - надо качественно удовлетворить потребность конечного покупателя в товаре. При ближайшем 


\begin{tabular}{|c|c|c|c|c|c|c|}
\hline \multirow{4}{*}{ Impact Factor: } & ISRA (India) & $=3.117$ & SIS (USA) & $=0.912$ & ICV (Poland) & $=6.630$ \\
\hline & ISI (Dubai, UAE & $=0.829$ & РИНЦ (Russia & $=0.156$ & PIF (India) & $=1.940$ \\
\hline & GIF (Australia) & $=0.564$ & ESJI (KZ) & $=8.716$ & IBI (India) & $=4.260$ \\
\hline & JIF & $=1.500$ & SJIF (Morocco & $=\mathbf{5 . 6 6 7}$ & OAJI (USA) & $=0.350$ \\
\hline
\end{tabular}

анализе простота оказывается условной композитивной, чтобы получить желаемый результат, придётся выстроить на рынке ансамбль из ценности товара (1), цены (2) и покупательской готовности потребителя. В этом смысле рынок действительно приобретает узловое значение для экономического развития. Данным акцентом экономической политики производителей можно объяснить концентрацию интересов на потребителя. Потребителя не актуально ждать, его необходимо активно искать и «обращать в свою веру».

В зарубежных аналитических обзорах появилась информация о том, что авангардно настроенные маркетологи, представляющие крупные компании, производящие товары массового спроса, предлагают существенно расширить формат соучастия с потребителями продукции вплоть до обсуждения рекомендуемой цены на изделие экономряда. Идея вполне разумная и практически осуществимая без особых затрат. Покупательские конференции здесь мало реальны, но развёрнутая практика проведения акций, рекламные действия с устройством показа товара, сообщением расчётной цены и просьбой дать потребительскую оценку планам достаточно перспективны и могут быть эффективными. Не надо недооценивать современного покупателя, его финансовой готовности, как не следует с завышением цены заставлять его оплачивать неквалифицированную политику производителя. Согласованные цены тоже не смертельны для предприятия. Есть всегда неиспользованные ресурсы: материаловедческие, технологические, организационные, активизируя которые производитель делает процесс рентабельным. За устойчивое положение на рынке в условиях усиления конкуренции и волатильности приходится платить. Возможно имеет смысл рационально осовременить то, что на «рынке» типа базар зовут «поторговаться».

Качество продукта, в практическом сознании, определяется через его способность удовлетворить потребности и ожидания конкретного потребителя. Качество продукта складывается из множества полезных свойств. На рис. 1 выделены основные качественные свойства товара.[3]

Новое для экономической теории понятие «ценность продукта» определяется как «совокупность ожидаемых потребителем параметров качества необходимого ему продукта». Из понятия «ценность продукта» «вырастили» «Дерево потребительской удовлетворенности».

Ценность продукта складывается из степени необходимости его потребителю и уровня качества (наличием требуемых характеристик у товара). На решение о покупке также влияют:

- уверенность покупателя в поставщике;

- доверие к производителю;

- информация, поступающая от других потребителей;

- накопленный опыт использования подобного продукта.

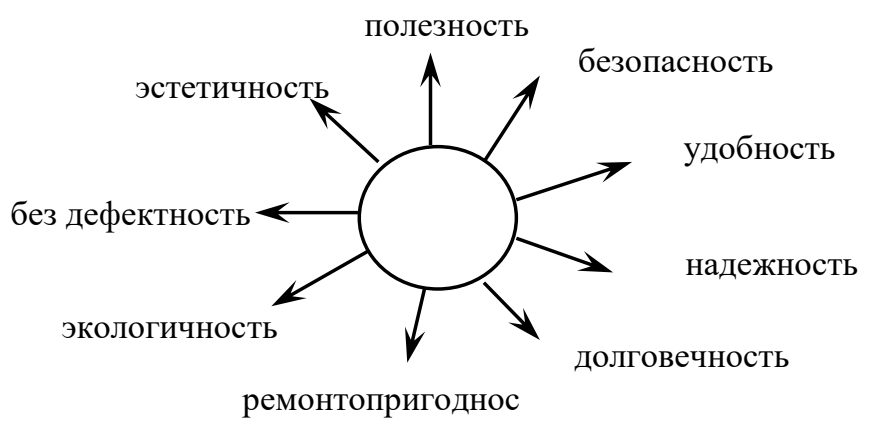

Рис. 1 Основные качественные свойства товара

Потребитель предпринимает решение о покупке товара, взвесив отношение предложенной цены продукта с предполагаемыми затратами. Чем выше уровень удовлетворенности потребителя, тем больше возможностей развития бизнеса, устойчивее его рыночное положение, то есть изготовление именно такого изделия, какое нужно данному потребителю и именно в требуемом объёме и определённое время.
Удалось ли в конечном счете выстроить унифицированную базовую модель управления качеством на основе стандартизации организационных и управленческих действий? Да, комплексная программа была разработана и апробирована международной практикой. Что же касается её системной оценки, то здесь мы бы от положительного вывода воздержались. До сих пор отсутствует ясность в толковании понятий «качество» и «стандарт». 


\begin{tabular}{|c|c|c|c|c|c|c|}
\hline \multirow{4}{*}{ Impact Factor: } & ISRA (India) & $=3.117$ & SIS (USA) & $=0.912$ & ICV (Poland) & $=6.630$ \\
\hline & ISI (Dubai, UAE & $=0.829$ & РИНЦ (Russia & $=0.156$ & PIF (India) & $=1.940$ \\
\hline & GIF (Australia) & $=0.564$ & ESJI (KZ) & $=8.716$ & IBI (India) & $=4.260$ \\
\hline & JIF & $=1.500$ & SJIF (Morocco & $=5.667$ & OAJI (USA) & $=0.350$ \\
\hline
\end{tabular}

Методологический резерв сложившегося во второй половине XX столетия - начале XXI подхода к совершенствованию стандартизации, по-видимому, исчерпан. Именно этим фактом можно объяснить отсутствие прорывных идей после работ А. Фейгенбаума, обобщивших практическое применение важных находок его предшественников - новаторов. Международные стандарты ИСО 9000-2000, отечественные ГОСТ P 57189-2016 / ISO/TS 9002-2016 являются линейным продолжением, то есть, по сути дела, рационализацией достигнутого. Необходимо в соответствии с новыми требованиями, сформировавшимися на этапе постнеклассического развития науки, дорабатывать методологические основания теории качества и стандартизации. В первую очередь развести понятия «качество» и «стандарт», чтобы, выяснив иерархию их отношений, соединить в новом подходе к решению проблемы управления качеством.

Для ясности повторимся: «качество» философская категория, её употребление в нефилософском контексте - научном, научнопрактическом, практическом - явление логически правомерное с уточнением, что прямой прагматической выгоды оно не принесет. Нужно спускаться с высоты философского обобщения на уровень практического действия, трансформировать понятие качества, наполняя его конкретным содержанием, отражающим специфику предметной деятельности, в нашем случае, - производства товарной продукции в условиях массового производства.

Философское понятие раскрывается в вербальной форме определения. Здесь особое значение имеет слово. Слов должно быть немного и немало, ровна столько, чтобы они передали суть качества. Суть качества - не то, что указывается в методических рекомендациях, не перечень существенных признаков, а системное их сосуществование. Качество товара воспроизводит - опосредованно через своеобразие физического субстрата - суть рынка, как структурного оформления двух субъектов - производителя товара и потребителя товара (продавцы составляют инфраструктуру и не в счет). Товаром является только то, что кому - то нужно, кроме производителя, следовательно, наряду с физической составляющей, в качестве товара присутствует потребительский интерес как надстроечное над физическим основанием явление.

Управлять философской категорией невозможно, её используют для разработки маршрута практического действия, в качестве навигатора движения от идеи к предметному (организационному) результату.
Качество товара, после взвешенного определения, нужно перевести в ту форму, которая соответствует производственному процессу, выразить в символах технического управления производством, - превратить в стандарт. Далее начинается уже история стандартизации. Понятие «качество» раскрывается в диалектике и управляется диалектикой. Понятие «стандарт» предполагает управление на производственном уровне. Оно описывается физически, химически, биологически, экологически, гигиенически и, в конце концов, - математически. На уровне стандарта формируется модель - физическая и математическая, a господствует системный подход. В системном подходе - будущее управлением стандартизацией.

Проиллюстрируем это на примере товара, производимого предприятиями легпрома. Ассортимент продукции настолько разнообразен и значителен, что возможность скептического восприятия нашего примера близка нулю и ею есть достаточно основания пренебречь.

Начнем с качества как высшей формы абстракции при определении товара. Качество есть то, отсутствие чего делает предмет безпредметным с точки зрения его существования. У находящихся в местах реализации продукции легпрома, на выставочных демонстрациях формируется ощущение, что вектор творчества один - создать нечто отличное, непохожее. У веера есть ограничения, а творчество не имеет пределов. Ощущение ложное, предел спрятан в многообразии, как говорил Фалес: " все - в одном». Надо всегда помнить об этом и держать качество в творчестве в виде собирающего ориентира. Обувь, носки, чулки, колготы не похожи друг на друга внешне, однако все они общего качества, - служат одеждой для ног и рук, то есть являются одеждой в широком смысле своего качества. Своя одежда есть у головы, отдельных частей головы, лица, туловища. Имеется различный уровень одежды внутренний, внешний. Легпром защищает человека и облагораживает его вид. Так получилось, что эволюция человека, лишив его значительной части естественных средств защиты, заставила решать проблему искусственным путем.

Производители в поисках нового обязаны руководствоваться требованиями типового качества продукции, обусловленного качеством предмета. Одежда должна способствовать сохранению естественных сил (здоровья), защищать от воздействия вредных для здоровья факторов, быть, по - возможности, легкой, эластичной, не сковывать движения в их естественном выражении, дышать вместе с кожей, 


\begin{tabular}{|c|c|c|c|c|c|c|}
\hline \multirow{4}{*}{ Impact Factor: } & ISRA (India) & $=3.117$ & SIS (USA) & $=0.912$ & ICV (Poland) & $=6.630$ \\
\hline & ISI (Dubai, UAE & $=0.829$ & РИНЦ (Russia & $=\mathbf{0 . 1 5 6}$ & PIF (India) & $=1.940$ \\
\hline & GIF (Australia) & $=0.564$ & ESJI (KZ) & $=8.716$ & IBI (India) & $=4.260$ \\
\hline & JIF & $=1.500$ & SJIF (Morocco & $=5.667$ & OAJI (USA) & $=0.350$ \\
\hline
\end{tabular}

минимизировать недостатки физического развития и быть массово доступной.

Далее формируется второй уровень понятия качества товара, обеспечивающий его потребительский вид. Это «качество» имеет уже субъективную базу, представляет духовное развитие потребителя, его личностный статус. Субъективная сторона качества товара дополняет объективную качество субстрата, она сообщает ему то, без чего товар потерял бы свою потребительскую значимость. Совмещенные в общем образе, объективная и субъективная стороны качества товара представляют предметную конкретность качества. В этом качестве философское толкование качества комплексуется с экономическим и техническим представлением. Качество, нагружаясь товарной конкретикой, трансформируется в стандарт производства, предполагающий техническое и математическое выражение в форме модели качества. Круг движения качества от абстрактного к конкретному выражению пройден ровно на половину. Начинается вторая часть истории качества товара - сравнение достигнуто с идеальным, совершенствование стандарта (модели) в соответствии с требованиями качества предмета (рис.2).

Ученые экономисты секвестировали методологию познания и управления до математического обеспечения, пытаясь осуществить провалившуюся в XIX веке идею О. Конта сделать каждую науку одновременно и философией. Одну из попыток подобного рода К. Маркс назвал « нищетой философии», за которую расплачиваться суждено не буржуазии, и не тем кто её обслуживает, платить определено потребителям. Поэтому, динамика приращения выглядит устойчиво: богатые и в кризис становятся богаче, остальные плавают по действительным волнам экономического движения.

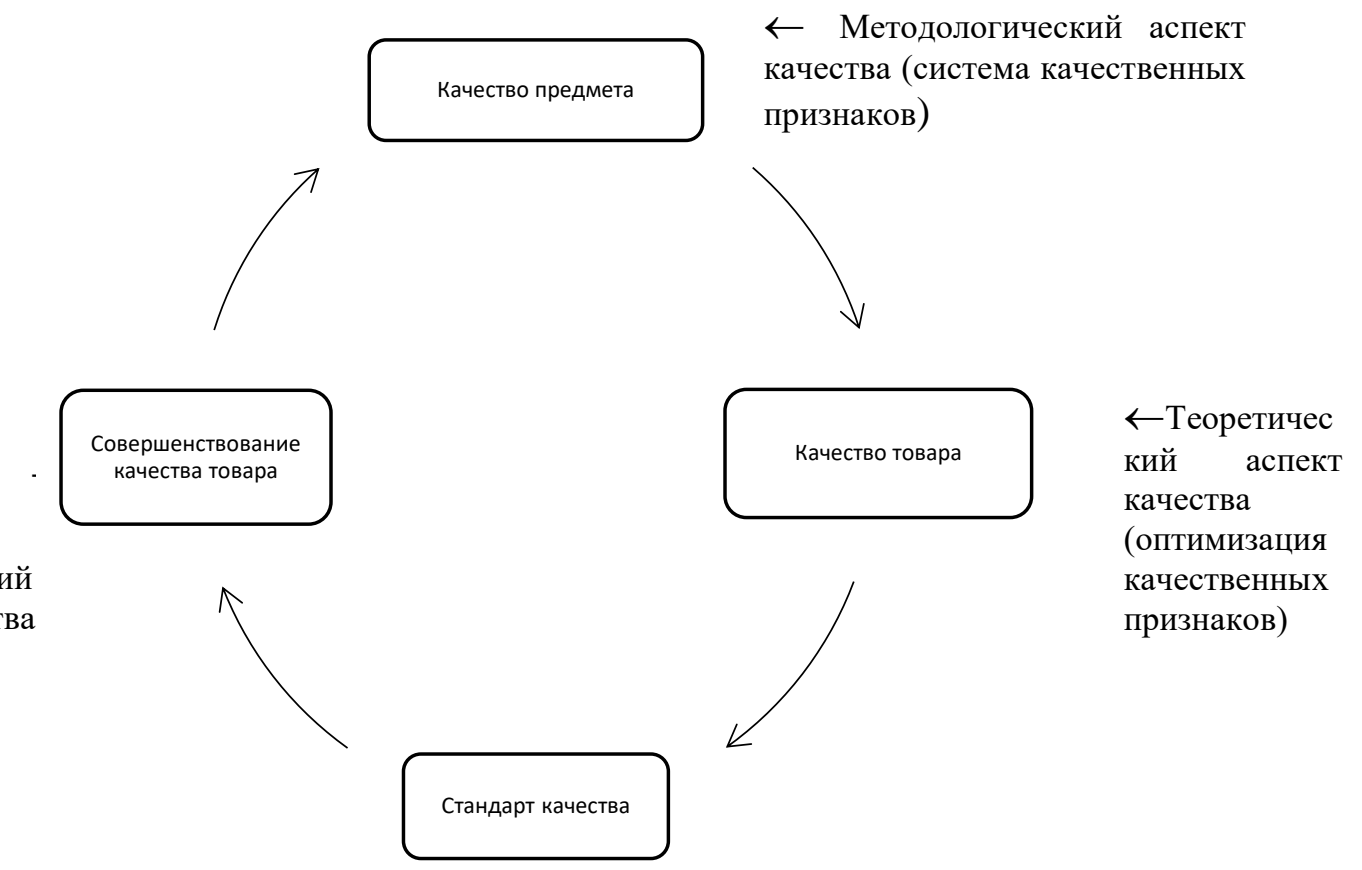

Аналитический аспект качества (направления прогресса)
Стандарт качеств $\leftarrow$ Теоретичес

кий аспект качества

оптимизация качественных признаков)

Рис. 2 Маршрут восхождения качества в процессе воспроизводства.

Как те, кто находится на воздушном шаре, терпящем бедствие, стараются сбросить балласт, чтобы дотянуть до нужного места, так и нынешние теоретики экономического движения стремятся отстегнуть от экономики всё, как они считают, неэкономическое, зачисляя в инфраструктуру деятельность, направленную непосредственно на развитие человеческого капитала, и при этом заявляют, что именно человеческий капитал является основным источником и резервом прирастания экономики. Удивляет то, как специалисты, завороженные термином «гуманизация производства», читают статистику.
«Обучение становится нормой жизни, восторженно констатируют авторы учебного пособия «Философские и социальные аспекты качества». Средние расходы американских компаний на обучение составляют около 1, 4\% фонда заработной платы . Когда это полтора проценты были показателем особого внимания к чему-либо. Налицо как раз дележ прибыли по остаточному признаку.

Итак, выделим суть нашего тезиса: стандартизация с первых же шагов своей истории имела целью определение и стабилизацию качества. Сначала непосредственно изделия, так 


\begin{tabular}{|c|c|c|c|c|c|c|}
\hline \multirow{4}{*}{ Impact Factor: } & ISRA (India) & $=3.117$ & SIS (USA) & $=0.912$ & ICV (Poland) & $=6.630$ \\
\hline & ISI (Dubai, UAE & $=0.829$ & РИНЦ (Russia & $=0.156$ & PIF (India) & $=1.940$ \\
\hline & GIF (Australia) & $=0.564$ & ESJI (KZ) & $=8.716$ & IBI (India) & $=4.260$ \\
\hline & JIF & $=1.500$ & SJIF (Morocco & $=\mathbf{5 . 6 6 7}$ & OAJI (USA) & $=0.350$ \\
\hline
\end{tabular}

как повлиять на технологию и организацию производства особых шансов не было, а с переходом к массовому производству, когда значительно выросло в результате деятельности значение организации производства, направление сместилась на процесс изготовления. На первый план вышла стандартизация производства. Считалось, если организация производства отвечает требованиям разработанного стандарта, то результат будет качественным.

Перевод стрелки на стандартизацию производства со стороны кажется оправданным действием. На самом деле, откуда взяться некачественности изделия, когда кругом только качественные действия. Наивные люди убеждены, что достаточно соединить качественный спирт с качественной водой, и вы получите качественную водку. У химиков иное мнение. Они утверждают, что для получения качественного спиртосодержащего напитка, надо ещё соблюсти порядок сочетания воды со спиртом, чтобы правильно запустить реакцию. Цеховое и отчасти мануфактурное производство подчинены были качественности товара. Ручной труд был малопроизводителен, но в пределах квалификации весьма мобильным. Отсюда и стопроцентное участие творчества в изделии. Качество изделия полностью подчиняло себе технологию и организацию производства. Бессмысленно фантазировать на тему: Страдивари или Амати пошли бы на изменение образца, если бы испытали трудности с изготовлением? Они ни на шаг не отступили бы от идеи её вещественной объективизации, искали решение в производстве и нашли бы. Совсем иной характер у массового производства любого типа нерачительного и рачительного. Если изделия, рекомендованное в массовое производство, не может быть без серьезной перестройки производства изготовлено, требует серьезных расходов, то проще подключить рационализаторов, чтобы «улучшить» изделие в интересах производства.

В качестве иллюстрации можно привести советский опыт. Потребители знали, что премьерные партии товара будут идеальными, но чем дальше, тем будет хуже. Немецкие автомобилестроители одни из самых квалифицированных, однако и они пошли на фальсификацию показателей работы двигателей, признались и были примерно оштрафованы. Аналогичные случаи неоднократно отмечались и в практике японских производителей. С сожалением в Российской Федерации с этим еще хуже дело обстоит. Основная причина процветающая коррупция.

Надо уяснить двойственную функцию стандартизации. Она сплотила в себе технологичность с политичностью. Ее значимость для совершенствования производства объективна это единственный магистральный путь продвижения экономики вперед, но, в тоже время - это и основное средство объективизации экономической политики, поэтому объективность стандартизации была и будет ориентирована политическими интересами. Стандартизацией можно управлять (и нужно!), следовательно, можно и манипулировать.

Придя во власть, Президент США Д. Трамп принял меры по выходу страны из Парижских соглашений по экологической политики, невзирая на осложнение отношений с европейскими партнерами, особо чувствительными к эффектам экологических перемен - материк мал, скученность населения и производства большое. Д.Трамп - человек бизнеса и бизнесполитика для него суть политики. Все остальное должно быть в подчинении. Д.Трамп взялся за перестройку экономического движения своей страны и стандарты он будет выстраивать, исходя из сугубо американских интересов, не напрягаясь инфраструктурными процессами, к которым Д.Трамп относит состояние природной среды. Через техническую форму стандартизации проявляется её политическая сущность.

И последний аргумент в пользу диалектического восприятия стандартизации Президент РФ объявил центральной экономической задачей создание цифрового производства. Цифры еще со времен пифагорейцев были символом предельной абстракции, за цифрой теряется предметность, её заменяет число, но не хаотично, а вполне определенно. Отдельно взятая цифра беспредметна. Иное дело определенное сочетание цифр, оно, с помощью определенного кода, воссоздает предмет в его наиболее точном выражении, что открывает практически неограниченные возможности идентифицирования и управления. Из управления, благодаря переводу действий в независимую от субъективного фактора сферу, изымается эмоционально - мотивационная составляющая субъектной деятельности, издержки профессиональной готовности специалиста. Как говорится: ничего личного, только в интересах дела. Плохо, когда недооценивается роль личности, еще хуже, когда в зависимости от личности оказывается судьба общего дела.

Управление производством, включая стандартизацию, нужно тщательно готовить с максимальной опорой на резервы профессиональной культуры специалистов, но динамику управления запущенным производством желательно поручить техническим программам и средствам. Так все будет надежнее. В июне 2018 года ледокольный флот России пополнился самым современным дизельным 


\begin{tabular}{|c|c|c|c|c|c|c|}
\hline \multirow{4}{*}{ Impact Factor: } & ISRA (India) & $=3.117$ & SIS (USA) & $=0.912$ & ICV (Poland) & $=6.630$ \\
\hline & ISI (Dubai, UAE & $=0.829$ & РИНЦ (Russia) & $=0.156$ & PIF (India) & $=1.940$ \\
\hline & GIF (Australia) & $=0.564$ & ESJI (KZ) & $=8.716$ & IBI (India) & $=4.260$ \\
\hline & JIF & $=1.500$ & SJIF (Morocco & $=5.667$ & OAJI (USA) & $=0.350$ \\
\hline
\end{tabular}

судном арктического класса для проводки караванов по Северному морскому пути в ежегодном режиме. Высота - с пятиэтажный дом, мощность основного двигателя 45000 л.с. Управляют судном 19 человек, что может быть убедительнее в пользу преимуществ технического управления производством. Но у технического управление есть свои слабые места. Среди них: высокий уровень энергетической зависимости, компьютерная безопасность не абсолютна, требования к личностным способностям специалистов в условиях персональной и командной ответственности повышенные, временами вплоть до эксклюзивных. Проблемы на производстве, как правило, создают люди, но именно в отсутствии квалифицированных специалистов возникают самые серьезные проблемы. Техническое стандартизированное управление - не панацея.

Попробуем сформулировать правила стандартизации. Основных, на наш взгляд, их два. Первое: стандартизация должна осуществляться в трех направлениях, связывая их в комплекс, определять стандарт изделия в рамках его функционального предназначения с учетом широкого понимания безопасности использования; регламентировать процесс производства и формировать потребительское отношение к изделию. Потребитель полноценный участник стандартизации. Без должного интереса потребителя к изделию, товар не будет востребован в масштабах, необходимых для устойчивого его производства.

Второе: стандартизация производства осуществляется на основе понятийного осмысления его положения в системе конкретноисторических условий, так как она обусловленна качеством этапа экономического развития. Как бы это не воспринималось сознанием, с этим надо мириться. Товар должен быть востребован не эксклюзивно, а в массовом масштабе, в противном случае производство перестанет быть массовым, растратит свое качество.

Ассортимент продуктов массового спроса в СССР был не велик, но качество товара потребителя удовлетворяло и позволяло производителю решать свои проблемы. Отход от разработанных в СССР стандартов производства позволил существенно развернуть ассортимент товаров ценою потери качества. Всё чаще в магазинах и рекламе встречаются советские бренды , которые вовсе не были в СССР ими, являясь рядовыми изделиями.

Понятия выражаются только в словах, их в цифры не переведёшь, в отличии от изделий. Еще раз обратим внимание на то, что понятия «качество» и «стандарт» соотносятся как общее и частное в характеристике явления. Реально управлять качеством можно только с помощью слов, а слово, по определению, обобщает отраженное явление и снимает его чувственно предметную конкретность, затрудняя практическое воздействие, снижая эффективность. Определяя качество предмета, мы всего лишь ограничиваем его и конкретизируем управление, задавая управлению вектор и цели. Чтобы управление обрело практический вид, необходимо иметь уже не образ предмета, а его предметное выражение. Здесь необходим предметный или адекватный ему чувственный, оцифрованный образец, который после технической обработки обретает форму программы практического действия. Цифровое производство построено на основе физического воздействия на объект и требует стандартизированную реальность качества. История известная как история управления качеством, по - существу есть история стандартизации производства, конкретизации качества в образец производства.

Первый опыт контрольного вмешательства в производственный процесс с целью придать ему устойчивость и определенное приращение можно обнаружить в деятельности цехов, отдельных производств, школ мастеров. Большинство знаменитых ваятелей Возрождения старались работать в командах каменотесов, непосредственно в местах добычи материала. Они искали в карьерах нужную для создания образа фактуру. Именно тогда появилась шутка: шедевр сделать просто - надо убрать все ненужное, лишнее, но прежде нужно найти основу. В цехах в интересах качества мастера тщательно проверяли изделия, наблюдали по ходу изготовления за работой подмастерьев, активно приобщали к секретам производства учеников, отбирая из них наиболее способных. Несмотря на то, что каждое изделие было индивидуальным, изготовленным мастером, оно проходило внутренний контроль, за которым был и внешний со стороны городских цеховых организаций. В последствие такую работу определят как фазу отбраковки.

По содержанию она была много богаче, синтетической, больше похожей на «выборку», чем на «отбраковку». Творчество двигало мастеров, мастера учились не меньше учеников. Они искали краски, грунт, основу, идеальные образы и ... ошибались. Творчество не щадит никого - ни великих, ни начинающих. Приходилось работать всем, а особенно мастерам, методом втыка. Понятие «брак» не такое простое, как кажется со стороны. Брак не всегда на виду, мастеров доставали скрытые его формы, проявляющиеся со временем. «Отбраковка» - не актом была как в массовом производстве, а технологией. Нам сегодня сложно заглянуть за достигнутый горизонт в развитии массового производства. Ясно только то, что «рачительная» 


\begin{tabular}{|c|c|c|c|c|c|c|}
\hline \multirow{4}{*}{ Impact Factor: } & ISRA (India) & $=3.117$ & SIS (USA) & $=0.912$ & ICV (Poland) & $=6.630$ \\
\hline & ISI (Dubai, UAE & $=0.829$ & РИНЦ (Russia & $=0.156$ & PIF (India) & $=1.940$ \\
\hline & GIF (Australia) & $=0.564$ & ESJI (KZ) & $=8.716$ & IBI (India) & $=4.260$ \\
\hline & JIF & $=1.500$ & SJIF (Morocco & $=\mathbf{5 . 6 6 7}$ & OAJI (USA) & $=0.350$ \\
\hline
\end{tabular}

его форма, пока скорее направление развития, чем фаза. Однако логика прогресса, выстроенная на преемственности, не исключает возвращение к какой-то части, характерной для цеховой организации. Массовость не должна быть тормозом творчества. В ней со временем обязательно раскроется многообразие под общей «крышей» множественного результата. Поэтому, следует тщательно исследовать производственный совершенствовавшийся в цеховой форме.

Современная отбраковка как действие, направленное на стандартизацию отсчитывается с последней четверти XIX столетия. Началом признается опыт заводов С. Кольта, полагают, что там родилась идея «стандартного качества». Если оценивать в системе нашей версии «качество стандарт», то это было подсознательным воплощением вывода Гегеля о диалектике восхождения познания от абстрактного понятия качества к конкретному понятию «стандарта» качественности изделия.

У С.Кольта сборка шла без предварительной подгонки деталей. Специально обученные контролеры проводили калибрование предварительно и отбраковывали некондицию, ускоряя тем самым основную - сборочную часть производства. Опыт С. Кольта в начале следующего столетия развили на автомобильном производстве Г. Форда и Г. Леланда («Кадиллак»). Г. Форд, введя конвейерную сборку убрал с конвейера контроль комплектующих, логично посчитав, что подобную работу нужно делать раньше. В итоге «входной контроль» соответствия калибрам стандарта заменили на «выходной контроль» на смежном производстве, что очистило от брака основное производство, сделало его качественно чище.

Далее процесс стандартизации пошел путем совершенствования достигнутого, в него включились теоретики Ф. Тейлор, А. Файоль., М. Вебер. В союзе с управляющими они выделили базовые принципы научного подхода к организации массового производства: системный подход к управлению; управление кадрами; делегирование ответственности; научное нормирование труда. Разработанная система управления производством вошла в историю как производственная система Г.Форда - Э.Тейлора. Имея бесспорные преимущества система Г.Форда - Э.Тейлора, содержала и серьезные дефекты, которые долгое время «дремали» в ее потенциале. Развитие производства в новых социальнополитических условиях активизации социалдемократических интересов неизбежно толкали систему Г.Форда - Э.Тейлора в тупик. Этому же способствовал и технологический прогресс, процесс превращения научных знаний в непосредственную производительную силу.
Стремление всеми средствами реализовать принцип не позволить дефектным изделиям дойти до потребителя не могло не завести производство в технологический структу рный кризис.

Более значимой стала перестройка организации управления качеством. На смену отделам технического контроля пришла аудиторская служба по качеству, ориентированная на проверку действительности системы обеспечения качества посредством выборочного контроля отдельных небольших выборок из общей партии изделий.

Следующим шагом совершенствования стандартизации производства стала концепция «менеджмента качества» Э. Деминга. Она формировалась и оптимизировалось на протяжении почти полвека, с 1950 по 1992 год. Опираясь на идеи В.Шухерта, Э.Деминг сформулировал три базовых «прогматических аксиомы»:

- всякая производственная деятельность сводима к стандартного вида техническому процессу и содержит резервы улучшения, которые необходимо выявить и мобилизовать;

- производство имеет две стандартные формы существования: стабильную и нестабильную, поэтому решение конкретных (текущих) проблем малоэффективно, необходимо вектор управленческой деятельности направить на фундаментальные изменения;

- основную ответственность за сбой в развитии производства должно брать на себя высшее руководство.

Учение Э. Деминга хорошо известно, оно получило широкое практическое применение. Нам хотелось обратить внимание не столько на составляющие содержание концепции структурные разделы, сколько акцентировать вопрос: чему обязан Деминг своим громким успехом, что способствовало эффективности применения разработанных им положений в реальной экономике?

Годы творчества Э. Деминга пришлись на два переломных в мировой экономике события. Прежде всего оказался мифом проект, рассчитанный на всемогущество технического прогресса. Повторилась история с наукой в эпоху Просвещения, когда казалось, что человечество нашло полноценную замену религии в лице науки. Наука является универсальным знанием, решит все проблемы. Надо только развернуть сознание масс лицом к науке, сделать Просвещение научным и всеобщим. Деминг раньше других понял и предупредил: мнение, что механизация, автоматизации и компьютеризация совершат прорыв в области устойчивости качественности производства, принадлежит к сфере трудностей в решении проблемы эффективности управления 


\begin{tabular}{|c|c|c|c|c|c|c|}
\hline \multirow{4}{*}{ Impact Factor: } & ISRA (India) & $=3.117$ & SIS (USA) & $=0.912$ & ICV (Poland) & $=6.630$ \\
\hline & ISI (Dubai, UAE & $=0.829$ & РИНЦ (Russia & $=\mathbf{0 . 1 5 6}$ & PIF (India) & $=1.940$ \\
\hline & GIF (Australia) & $=0.564$ & ESJI (KZ) & $=8.716$ & IBI (India) & $=4.260$ \\
\hline & JIF & $=1.500$ & SJIF (Morocco & $=5.667$ & OAJI (USA) & $=0.350$ \\
\hline
\end{tabular}

качеством, также, как настрой получения положительных результатов в кратчайшие сроки.
Э.Деминг предложил свою философию в виде «ценной реакции»(рис.3).[4]

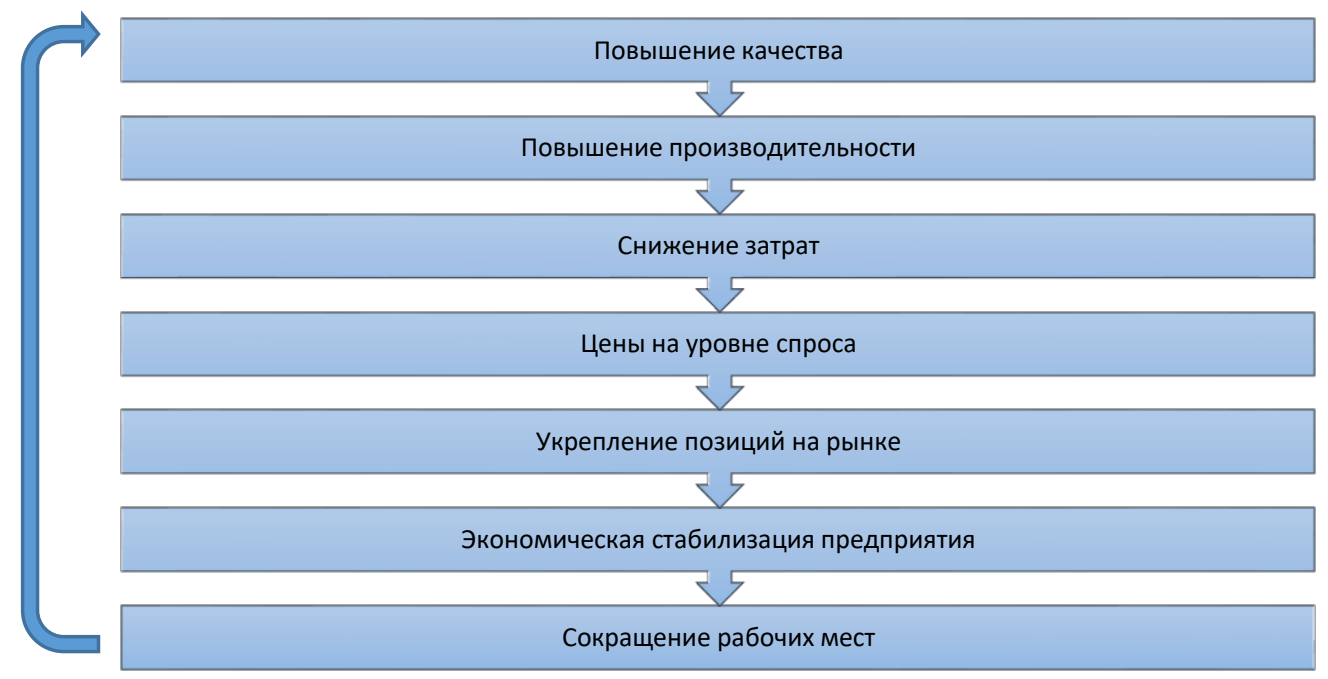

Рис.3 «Цепная реакция» (по Э. Демингу)

Сравнивая философию управления В.Шухерта и Э.Деминга, видить на сколько зависима экономика и экономическая теория от трендов общественного развития. В.Шухерт отразил в своей концепции социальнополитический и культурный настрой, сложившийся после кризиса, вызванного Первой мировой войной. Европа и США с Канадой приходили в себя трудно, ибо война на уничтожение поставила под вопрос достоинства демократии. В то же время определенная часть мыслящего человечества пыталась переосмыслить ситуацию и спасти имидж демократических преобразований, веря в силу творческого начала homo sapiens. Экономисты первой половины XX века почувствовали решающую роль в развитии производства человеческого фактора, поставили под сомнение ставку Ф.Тейлора, Г.Форда, А.Файоля на технический фактор. До конкретизации человеческого фактора в человеческий капитал было еще полвека, однако как и в природе, в обществе катаклизмы больше вредят, чем приносят пользы. Революции действительно являются локомотивами в истории с поправкой на то, что не временной фактор образует ядро революции. Революции, будь то в промышленности, технике, науке, культуре, общественном устройстве, - это прежде всего процесс смены прежнего качества на новое. Революция тождественна качественности преобразования, она идеалы делает стандартами практической жизни. Фактор времени революционных преобразований вторичен и обусловлен конкретностью исторической реальности. Но одно инвариантно в истории решающая сила человека как первичного исторического фактора. История есть процесс человеческого творчества, правда, далеко не всегда удачного. Все равно и тогда исправлять, кроме человека, некому.

Заслуга В.Шухерта и Э.Деминга состояла в том, что они устояли на платформе классической политической экономии, не поддались многочисленным «соблазнам» - техническим, статистическим и прочим. Их логика отличалась уверенностью в историческую силу субъективности человека как личности. Взвесив на «весах» истории технику и творчество личности, они подтвердили, что прирастание капитала осуществляется человеком. Техника и бытийно и функционально зависит от человека.

И здесь время сработало на стороне Э.Деминга. Пришла пора возрождения Японии.

Война разрушила экономику страны, но не подорвала самурайский дух. Японцев природа научила держать удары судьбы. Национальная воля готова была вернуть стране былое величие в Тихоокеанском регионе, жители государства «восходящего солнца» хорошо понимали, что путь возрождения лежит через индустриализацию разрушенного производственного потенциала. Не знали только как ее осуществить. В самом конце 1940-х годов ведущие японские специалисты объединились в Японский союз ученых и инженеров - JUSE. Внутри Союза возникла группа, нацелившаяся на изучение промышленного опыта США. Она установила зависимость прогресса в управлении качеством с повышением производительности труда. Попытались разобраться в механизме установленной связи.

Неформальным лидером этой группы был К. Исикава - будущий инициатор «японского чуда». JUSE в 1950 году пригласил Э. Деминга, чтобы 


\begin{tabular}{|c|c|c|c|c|c|c|}
\hline \multirow{4}{*}{ Impact Factor: } & ISRA (India) & $=3.117$ & SIS (USA) & $=0.912$ & ICV (Poland) & $=6.630$ \\
\hline & ISI (Dubai, UAE & $=0.829$ & РИНЦ (Russia) & $=0.156$ & PIF (India) & $=1.940$ \\
\hline & GIF (Australia) & $=0.564$ & ESJI (KZ) & $=8.716$ & IBI (India) & $=4.260$ \\
\hline & JIF & $=1.500$ & SJIF (Morocco & $=5.667$ & OAJI (USA) & $=0.350$ \\
\hline
\end{tabular}

лучше познакомиться с технологией американского промышленного развития, но, в отличии от российских реформаторов 1990-хнулевых годов, японцы хорошо сами подготовились. Они не чуда ждали от американцев, а «информацию к размышлению».

К.Исикава свои размышления сконцентрировал в трех выводах:[5]

- все экспериментальные инженерные работы должны быть адэкватно определены статистически. С целью повышения уровня знаний статистических методов анализа, по инициативе JUSE на промышленном факультете Токийского университета ввели обязательный курс «как пользоваться экспериментальными данными»;

- зависимость от импорта сырья и продовольствия можно преодолеть исключительно посредством роста и расширения ассортимента экспорта причем должна быть четкая нацеленность промышленности на производство высококачественной продукции, чтобы не разбазаривать ресурсы;

- необходимо осуществить переориентацию сознания специалистов и в обществе в целом на менеджмент качественной высокотехнологической продукции. У Японии не было альтернативы этому пути, так как финансовые резервы не позволяют планировать тотальную модернизацию производства.

Э. Деминга пригласили, чтобы идти к цели не по американски, а по японски, двигаясь не от больших финансов, а от национального менталитета, в котором культура труда занимала важнейшее место.

Идеи Э.Деминга, К.Исикавы, Й.Джурана реализовались, подтвердив важность встречных курсов движения национальных интересов и инновационного, креативного, творческого мышления не ангажированных, честных специалистов. «Японское чудо» - продукт взаимодействия научной мысли, критического анализа производственного опыта передовых экономик и особенностей японского национального самосознания. К.Исикава, Э.Деминг и Й.Джуран счастливо встретились в том самом месте и в то время, когда ситуация вызрела и объективно - надо было спасать и возвращать экономический потенциал страны и субъективно-японская нация обладает высокой и сплоченной ответственностью за свой имидж. Только японская команда, проиграв на последних секундах матч чемпионата мира 2018г. все убрала в своей раздевалке и оставила записку на русском языке с единственным словом: «Спасибо». Разумеется прямого отношения к теме нашего исследования данный факт не имеет, но он показателен в качестве характерного штриха к национальному характеру.
«Дорожную карту» возрождения экономики Японии в статусе одного из мировых лидеров качественной организации производства восстановил Б.С. Алешин с коллегами [6]. Нас больше интересуют уроки движения японских специалистов к цели. Их вполне достаточно, чтобы не пройти мимо, но такая уж особенность у наших любителей порулить экономикой по американским лоциям вслед за Гайдаром и его учениками. Они очень не любят, когда что-то не хочет двигаться в колее либеральной экономической теории, отлучающей государство от производства.

Отечественные демреформаторы провалились дружно потому, что знали от чего следует избавиться, но не знали как цивилизованно это сделать и главное, - чем заменить, исходя из российской специфики реальности. Японцы же заранее определились с тем, что будут делать. Им нужна была только конкретика - «дорожная карта» движения, поэтому они и призвали Э. Деминга в качестве навигатора или лоцмана.Э.Деминг блестяще справился. Э.Демингу за лекции платили японцы, нашим «прорабам» - Copec. Японцы спасали национальный престиж, наши - рубили национальные исторические корни и воровали где только могли. Не удивительно что японцы через 30 лет (к началу 1980-х гг) производили 40\% мирового производства цветных телевизоров, 75\% -транзисторных приемников и $95 \%$ видеомагнитофонов. РФ тридцать лет спустя всё никак не может восстановить разрушенный потенциал.

Итак, чему же учит японский опыт (именно учит, то есть направляет мысль), а не выписывает рецепты):

- качество - это время, годы последовательного, напряженного труда, сопряженного с необходимостью собирать и анализировать творческие подходы;

- качество - продукт взаимодействия с потребителем, построенного на партнерских отношениях взаимоуважения. Потребитель при этом понимается предельно широко, включая всех участников производства;

- тотальность участия в достижении качественных результатов;

- системно налаженный аудиторский контроль;

- ключевая роль в получении устойчивости качества деятельности мастеров и бригадиров, их непрерывная переподготовка в различных формах, включая специальные программы национального и регионального телевидения;

- особое внимание к мобилизации физических, нравственных и креативных способностей рабочих; 


\begin{tabular}{|c|c|c|c|c|c|c|}
\hline \multirow{4}{*}{ Impact Factor: } & ISRA (India) & $=3.117$ & SIS (USA) & $=0.912$ & ICV (Poland) & $=6.630$ \\
\hline & ISI (Dubai, UAE & $=0.829$ & РИНЦ (Russia & $=0.156$ & PIF (India) & $=1.940$ \\
\hline & GIF (Australia) & $=0.564$ & ESJI (KZ) & $=8.716$ & IBI (India) & $=4.260$ \\
\hline & JIF & $=1.500$ & SJIF (Morocco & $=5.667$ & OAJI (USA) & $=0.350$ \\
\hline
\end{tabular}

- пропаганда качества и его ключевого значения для развития производства;

- и, наконец, то, что приводит в бешенство либералов - управленцев,- необходимость государственной последовательной экономической политики, особенно в производстве экспортной продукция; обязательная государственная сертификация продукции для других стран. Попытки продать вне государства несертифицированные товары приравниваются к контрабанде. Господдержка экспорта, помощь в продвижении товаров на мировой рынок.

Последним штрихом в японской программе управления качеством целесообразно рассматривать идею деления проблем на внезапные и хронические, предложенную Й. Джураном. Предусмотреть в планировании все возможные проблемы не реально и поэтому не нужно. Достаточно иметь мобилизационные резервы, обеспечивающие устойчивость движения. Целью должны быть хронические проблемы, ставшие частью организации - на самом деле дезорганизации-производства. Хронические проблемы чаще всего носят латентный характер, они как бы адаптированы производством. Не секрет, что безотходной технологии не бывает, следовательно, допуски являются естественным состоянием управления качеством. Приказы, постановления, призывы, лозунги здесь бессильны. Раз хронические проблемы сделались частью организации производства, то и преодоление их необходимо осуществлять в рамках сложившегося порядка.

Процесс решения хронических проблем Й.Джуран представил как своего рода «дорожную карту» движения с четырьмя узловыми фазами станциями. Фазы - станции - этапы решения, на них производятся определенные действия в заданной организацией движения последовательности. Составляющие проблемы на этапах Й.Джуран называл «основными фазами». Схема Й. Джурана по-прежнему актуальна в качестве «информации к размышлению». Мы её приводим (рисунок 4)

\begin{tabular}{|l|l|}
\hline \multicolumn{1}{|c|}{ Этап решения проблемы } & \multicolumn{1}{|c|}{ Составляющие проблемы (фазы) } \\
\hline Разработка основных положений & 1. Составление перечня проблем и выявление приоритетов. \\
проекта & 2. Определение состава, ответственности и полномочий рабочих \\
& групп. \\
\hline Диагностика & 3. Анализ симптомов \\
& 4. Формулирование версий \\
& 5. Верификация версий \\
& 6. Выявление причин \\
\hline Поиск решения & 7. Поиск оптимальных решений \\
& 8. Разработка необходимых мероприятий \\
& 9. Преодоление сопротивления \\
& 10. Внедрение решений \\
\hline Удержание достигнутых & 11. Проверка эффективности результатов внедрения. Регулярное \\
результатов & сравнение достигнутых результатов с запланированными. \\
\hline
\end{tabular}

Рис. 4 Фазы решения проблем (по Й. Джурану)

Первый опыт контрольного вмешательства в производственный процесс с целью придать ему устойчивость и определенное приращение можно обнаружить в деятельности цехов, отдельных производств, школ мастеров. Большинство знаменитых ваятелей Возрождения старались работать в командах каменотесов, непосредственно в местах добычи материала. Они искали в карьерах нужную для создания образа фактуру. Именно тогда появилась шутка: шедевр сделать просто - надо убрать все ненужное, лишнее, но прежде нужно найти основу. В цехах в интересах качества мастера тщательно проверяли изделия, наблюдали по ходу изготовления за работой подмастерьев, активно приобщали к секретам производства учеников, отбирая из них наиболее способных. Несмотря на то, что каждое изделие было индивидуальным, изготовленным мастером, оно проходило внутренний контроль, за которым был и внешний со стороны городских цеховых организаций. В последствие такую работу определят как фазу отбраковки.

По содержанию она была много богаче, синтетической, больше похожей на «выборку», чем на «отбраковку». Творчество двигало мастеров, мастера учились не меньше учеников. Они искали краски, грунт, основу, идеальные образы и ... ошибались. Творчество не щадит никого - ни великих, ни начинающих. Приходилось работать всем, а особенно мастерам, методом втыка. Понятие «брак» не такое простое, как кажется со стороны. Брак не всегда на виду, мастеров доставали скрытые его формы, проявляющиеся со временем. «Отбраковка» - не 


\begin{tabular}{|c|c|c|c|c|c|c|}
\hline \multirow{4}{*}{ Impact Factor: } & ISRA (India) & $=3.117$ & SIS (USA) & $=0.912$ & ICV (Poland) & $=6.630$ \\
\hline & ISI (Dubai, UAE & $=0.829$ & РИНЦ (Russia & $=0.156$ & PIF (India) & $=1.940$ \\
\hline & GIF (Australia) & $=0.564$ & ESJI (KZ) & $=8.716$ & IBI (India) & $=4.260$ \\
\hline & JIF & $=1.500$ & SJIF (Morocco & $=5.667$ & OAJI (USA) & $=0.350$ \\
\hline
\end{tabular}

актом была как в массовом производстве, а технологией. Нам сегодня сложно заглянуть за достигнутый горизонт в развитии массового производства. Ясно только то, что «рачительная» его форма, пока скорее направление развития, чем фаза. Однако логика прогресса, выстроенная на преемственности, не исключает возвращение к какой-то части, характерной для цеховой организации. Массовость не должна быть тормозом творчества. В ней со временем обязательно раскроется многообразие под общей «крышей» множественного результата. Поэтому следует тщательно исследовать производственный совершенствовавшийся в цеховой форме.

В союзе с управляющими они выделили базовые принципы научного подхода к организации массового производства: системный подход к управлению; управление кадрами; делегирование ответственности; научное нормирование труда. Разработанная система управления производством вошла в историю как производственная система Г. Форда - Б. Тейлора. Имея бесспорные преимущества система Г. Форда - Б. Тейлора, содержала и серьезные дефекты, которые долгое время «дремали» в её потенциале. Развитие производства в новых социальнополитических условиях активизации социалдемократических интересов неизбежно толкали систему Г. Форда - Б. Тейлора в тупик. Этому же способствовал и технологический прогресс, процесс превращения научных знаний в непосредственную производительную силу. Стремление всеми средствами реализовать принцип не позволить дефектным изделиям дойти до потребителя не могло не завести производство в технологический структу рный кризис.

К этому же двигало отсутствие в теории управления четкого понимания качества и стандарта. Их поменяли вместо того, чтобы рассматривать в развитии. Наиболее заметным и чувствительным было отождествление качества и стандарта в сфере производства товаров массового потребления, где понятие качества изделия отражает дуалистичность природу товара.

Товар, предназначенный для субъективного, точнее, субъектного пользования личностью или социальной группой должен быть качественным объективно,- физически и субъективно, доставлять удовлетворение своим физическим качеством потребителю. Наивно полагать, что только рекламой физического совершенства изделия, можно вызвать расположение к нему потребителя. Такой потребитель должен быть субъективно никаким. Интерес к физическому качеству товара можно сформировать демонстрацией его возможностей, но для того, чтобы интерес сформировался в потребность купить его этого мало. Товар должен пленить чувства покупателя, а это процесс иррациональный, глубоко интимный по природе, выражающий индивидуальность потребителя. Особенно, если потребитель приобщён к значительному ассортименту, разборчив и привередлив.

Качество товаров массового потребления не сводимо к системе физических параметров, но она в их качестве существует, как своего рода ядро. И также, как атом не исчерпывается наличием ядра, так и качество такого рода товаров не ограничивается системой физических характеристик. Напротив, стандарт является чисто физическим феноменом и требует четкого описания в физических единицах измерения. К понятию «качество товара» следует идти через рынок, а «стандарт товара» определять в условиях научно-технического творчества.

Когда стремление к тотальности организации контроля за качеством вступила в противоречие с тотальной целевой установкой на повышение эффективности производства и стало ясно, что прежним способом конфликт не разрешить, В. Шухерт, работавший в отделе технического контроля американской фирмы «Вестерн Электрик», предложил сместить акцент управления качеством на организацию динамики производственного процесса. Новаторство В. Шухерта заключалось в том, что он посмотрел на производство и качество производства как движение и в этом контексте понял главное в качестве движения: во-первых, достижение устойчивости, во-вторых, неизбежность отклонения от направления движения(рис.5). Перевел особенности движения на решение задачи получить качественный результат и получил два вывода: искомое качество можно получить только в условиях устойчивого движения производства, следовательно нужно стабилизировать производство в определенных качественных параметров (1), и качество - это обобщающая характеристика процесса, которая реально представляет собою вариации. Вариации необходимо заключить в определенные рамки (2). 


\begin{tabular}{|c|c|c|c|c|c|c|}
\hline \multirow{4}{*}{ Impact Factor: } & ISRA (India) & $=3.117$ & SIS (USA) & $=0.912$ & ICV (Poland) & $=6.630$ \\
\hline & ISI (Dubai, UAE & $=0.829$ & РИНЦ (Russia & $=\mathbf{0 . 1 5 6}$ & PIF (India) & $=1.940$ \\
\hline & GIF (Australia) & $=0.564$ & ESJI (KZ) & $=8.716$ & IBI (India) & $=4.260$ \\
\hline & JIF & $=1.500$ & SJIF (Morocco & $=5.667$ & OAJI (USA) & $=0.350$ \\
\hline
\end{tabular}

Верхняя контрольная граница Линия искомого качества

Нижняя контрольная граница

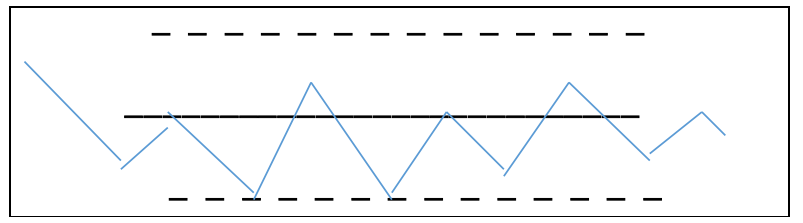

Рис. 5. График качества
Задача достижения качественности производства обрела у В.Шухерта технический вид и смысл: избежать вариаций параметров полученного качества изделий невозможно, нужно стремиться уменьшить вариации. Критерий качества - устойчивость производства в статическом смысле, то есть сближение вариаций с центральной линией. Одним из важнейших факторов решения задачи В. Шухерт назвал перестройку личностного взаимодействия сотрудничество, командную организацию.

В.Шухерт первым приблизился к толкованию стандарта в условиях массового производства, представив качество производства и товара как статистическую форму, предполагающую определенное колебание, которое получило название допуска В. Шухерта. В.Шухерт не ввел понятие статистической модели стандарта, но оно с необходимостью формировалось на основе его инновационных идей. Б.С. Алешин с соавторами сравнение систем управления качеством Ф.Тейлора и В. Шухерта свели в таблицы, наглядно убеждающие, насколько продвинулась управленческая мысль(рис.6).

\begin{tabular}{|c|c|}
\hline \multicolumn{2}{|c|}{ Сравнение систем } \\
\hline Система Б. Тейлора & Система В.Шухерта \\
\hline $\begin{array}{l}\bullet \\
\text { изделий } \\
\text { • } \\
\text { • } \\
\text { Изготовленление требований к качеству } \\
\text { Инспекция изделий } \\
\text { исполнителя (штрафы, увольнение) } \\
\text { Административное воздействие на }\end{array}$ & $\begin{array}{l}\bullet \\
\bullet\end{array}$ \\
\hline 口 & 口 \\
\hline 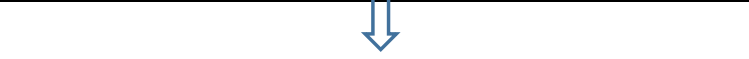 & 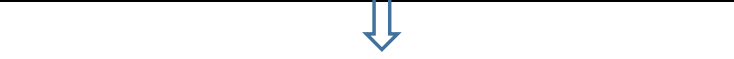 \\
\hline $\begin{array}{l}\text { Каждый элемент выполняется разными людьми, } \\
\text { что сопровождается конфликтом интересов. }\end{array}$ & $\begin{array}{l}\text { Каждый элемент выполняется командой, у } \\
\text { которой есть общая цель - снижение вариаций. }\end{array}$ \\
\hline
\end{tabular}

\section{Рис. 6 Сравнение систем Б. Тейлора и В.Шухерта}

В. Шухерт попытался придать управлению качеством человеческое лицо. Он подчеркнул значение внутренней, в том числе личностной, мотивации. Но радикально изменить положение работника в производстве он не стремился. Отчуждение личности принципиально оставалось прежним, поэтому мотивация поддерживалась преимущественно финансовой оценкой деятельности. Исследователи опыта В.Шухерта явно переоценивали его содержание, вводя в характеристику такую реакцию работников как «радость от получения результатов»; «удовольствие от командной работы, признание заслуг коллегами и руководстом»; «ощущение своей значимости» и т.п. Адекватнее было сказать, что метод В.Шухерта заставил учиться менеджеров тому, что именуется гуманитарными знаниями, формирующие предприятиям устойчивое финансовое положение.

В традиционной для нашего случая схеме формирования ассортимента закладывалась дифференциация, основанная на классификации обуви по трём признакам:

- назначению (бытовая; специальная);

- половозрастному признаку (основа ГОСТ 3927-88. Колодки обувные - пинетки, для ясельного возраста, малодетская, дошкольная, для 


\begin{tabular}{|c|c|c|c|c|c|c|}
\hline \multirow{4}{*}{ Impact Factor: } & ISRA (India) & $=3.117$ & SIS (USA) & $=0.912$ & ICV (Poland) & $=6.630$ \\
\hline & ISI (Dubai, UAE & $=0.829$ & РИНЦ (Russia & $=0.156$ & PIF (India) & $=1.940$ \\
\hline & GIF (Australia) & $=0.564$ & ESJI (KZ) & $=8.716$ & IBI (India) & $=4.260$ \\
\hline & JIF & $=1.500$ & SJIF (Morocco & $=\mathbf{5 . 6 6 7}$ & OAJI (USA) & $=0.350$ \\
\hline
\end{tabular}

школьников-девочек, девичья, для школьниковмальчиков, мальчиковая, женская, мужская);

- условиям эксплуатации (род профессиональной деятельности, сезонность, климатическая зона).

Опираясь на другие источники, обувь по своему назначению можно разделить на бытовую (повседневную, модельную, домашнюю) и специальную (производственную, спортивную, ортопедическую, медицинскую).

Однако такое деление ассортимента имеет ряд существенных недостатков. Оно не позволяет выявить группы населения с различными стилем, уровнем жизни и вкусовыми предпочтениями. Деление же по половозрастному признаку подразумевало различные антропометрические характеристики потребителей в зависимости от возраста и пола, но не учитывало возрастные отличия стиля жизни и приоритеты потребностей.

Потребности населения в товарах закладываются исторически. Они определяются уровнем развития общественного производства, благосостоянием и культурой общества и могут меняться с течением времени.

Характеристика ассортимента включает в себя такое понятие как мобильность. По определению маркетинга мобильность неотложное исполнение принятых решений, проведение исследований в строго установленные сроки.

Применение термина «мобильность» в отношении обувного ассортимента заключается в быстрой сменяемости моделей ассортимента в зависимости от конъюнктуры рынка и требований потребителей, предъявляемых к обуви. $\begin{array}{crr}\text { Каждая } & \text { эпоха } & \text { характеризуется } \\ \text { приверженностью } & \text { к } & \text { определённым }\end{array}$ тектоническим формам, колориту, масштабности, пропорциям и т.п. Этот устойчивый характер формальных средств художественной выразительности называют стилем эпохи. Под стилем в искусстве понимается исторически сложившаяся устойчивая общность образной системы средств и приёмов художественной выразительности, обусловленная единством идейного содержания искусства эпохи. Основное условие образования стиля - единство мироощущения и средств его выражения. К факторам, влияющим на формирование стиля, относятся:

- $\quad$ общественно-экономические

отношения,

философские идеи,

преобладающие

мировоззрение,

эстетический идеал эпохи,

уклад жизни,
- $\quad$ природно-климатические

условия,

$-$

Долгое время наблюдалось чёткое разделение на четыре основных стиля: романтический, классический, спортивный, фольклорный. За последние годы к этим четырём стилям добавился самостоятельно существующий пятый стиль в обуви - этно.

В практике маркетинга существует ещё принцип, учитывающий степень экстравагантности или консервативности потребителей. По своей реакции на новые явления потребителей делят на пять категорий:

$\begin{array}{ll}- & \text { суперноваторы }(2,5 \%) ; \\ - & \text { новаторы }(13,5 \%) ; \\ - & \text { обыкновенные }(34 \%) ; \\ - & \text { консерваторы }(34 \%) ; \\ - & \text { суперконсерваторы }(16 \%) .\end{array}$

По мнению отечественных и зарубежных исследователей, такую дифференциацию необходимо также учитывать при формировании структуры ассортимента [7].

По степени приверженности к брендам потребителей можно разделить на следующие группы:

безоговорочные приверженцы - это потребители, которые постоянно покупают товар одного и того же предприятия ( например, ООО « Егорьевская обувная фабрика»);

терпимые приверженцы - это потребители, которые привержены к двум-трём товарным брендам;

непостоянные приверженцы - это потребители, переносящие свои предпочтения с одного бренда на другой;

странники - это потребители, не проявляющие приверженности ни к одному предприятию.

Такое разделение потребителей целесообразно использовать, когда товар покупается с краткосрочной периодичностью, например, один раз в неделю или месяц.

Принцип экономической дифференциации потребителей практически рекомендуется осуществлять по уровню доходов и наличию того или иного имущества (автомобиль, недвижимость и т.д.). Одним из наиболее распространённых способов такой дифференциации продукции, используемая на зарубежных рынках, это деление ассортимента по ценовым точкам. Для стабильных рынков экономическая дифференциация предполагает сочетание экономических и семантических свойств продукции, а в количественном отношении имеет устоявшиеся доли сегментов. Такое тесное сочетание свойств не характерно для наших регионов, где уровень доходов не предполагает 


\begin{tabular}{|c|c|c|c|c|c|c|}
\hline \multirow{4}{*}{ Impact Factor: } & ISRA (India) & $=3.117$ & SIS (USA) & $=0.912$ & ICV (Poland) & $=6.630$ \\
\hline & ISI (Dubai, UAE & $=0.829$ & РИНЦ (Russia & $=0.156$ & PIF (India) & $=1.940$ \\
\hline & GIF (Australia) & $=0.564$ & ESJI (KZ) & $=8.716$ & IBI (India) & $=4.260$ \\
\hline & JIF & $=1.500$ & SJIF (Morocco & $=5.667$ & OAJI (USA) & $=0.350$ \\
\hline
\end{tabular}

единой культурной основы и психологии потребителя. Поэтому очевидно, что заимствование западной структуры потребителей невозможно.

Способ деления групп людей по их принадлежности к тому или иному потребительскому типу известен как шкала Ценностей и стиля жизни $\left(\mathrm{VALS}^{\mathrm{tm}}\right)$. Данный вариант классификации первоначально был разработан в 1978 году Арнольдом Митчеллом из компании SRI International (прежде Стенфордский исследовательский институт).

В рамках системы VALS ${ }^{\mathrm{tm}}$ выделяются ресурсы, включающие полный комплекс психологического, физического и демографического потенциала, на который опирается потребитель. В понятие ресурсов входят образование, доход, уверенность в себе, здоровье, стремление покупать, интеллект и энергичность.

Суммируя информацию, полученную в результате проведённого исследования, составлена структурная схема формирования менталитета потребителей обуви, представленная на рисунке. Предложенное структурирование может быть использовано при планировании промышленного ассортимента для регионов ЮФО и СКФО. И только во взаимосвязи всех выше рассмотренных факторов можно будет утверждать о высокой стабильности финансовых результатов деятельности обувных предприятий регионов ЮФО и СКФО, объединённых в инновационный центр [7].

Формирование ассортимента обуви с учётом её конкурентоспособности - это сложный процесс, осуществляемый с учётом действия целого ряда факторов, исследование которых должно базироваться на анализе существующего рынка обуви, а также на прогнозировании тенденций в социальной, экономической и производственной областях.

Формированию ассортимента предшествует разработка предприятием ассортиментной концепции. Она представляет собой направленное построение оптимальной структуры обувной высококачественной продукции, при этом за основу принимаются с одной стороны, необходимость обеспечения наиболее эффективного использования предприятием сырьевых, технологических, финансовых и иных ресурсов с тем, чтобы производить изделия с низкими издержками, а с другой - удовлетворения требований определённых групп потребителей с учётом их особенностей и возможностей (рисунок 7).

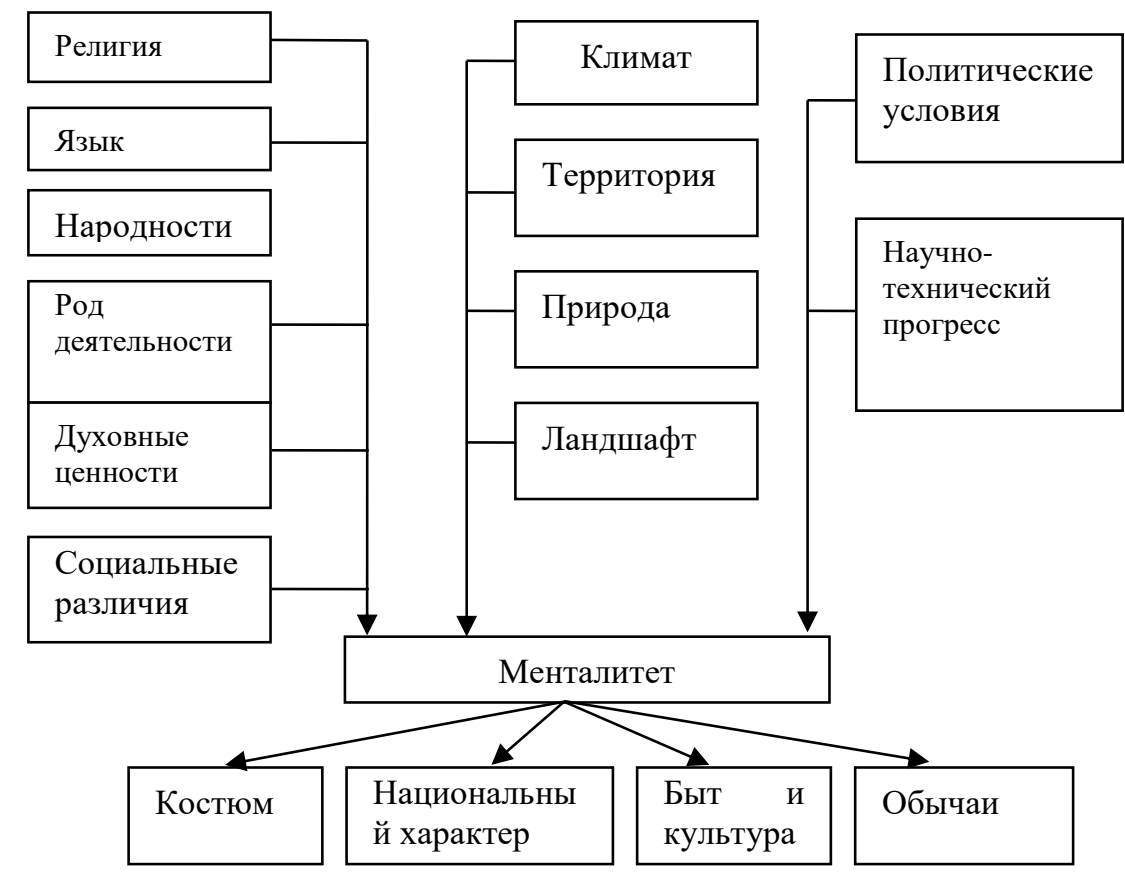

Рисунок 7. Структурная схема формирования менталитета потребителей продукции

Для создания конкурентоспособной высококачественной продукции обувным предприятиям требуется расширять и обновлять ассортимент, обеспечивать высокую динамику сменяемости моделей, увеличивать объёмы и повышать эффективность модельноконструкторских проработок, качество и удовлетворённость населения обувью.

При разработке или обновлении ассортимента обувное предприятие обязано 


\begin{tabular}{|c|c|c|c|c|c|c|}
\hline \multirow{4}{*}{ Impact Factor: } & ISRA (India) & $=3.117$ & SIS (USA) & $=0.912$ & ICV (Poland) & $=6.630$ \\
\hline & ISI (Dubai, UAE & $=0.829$ & РИНЦ (Russia) & $=0.156$ & PIF (India) & $=1.940$ \\
\hline & GIF (Australia) & $=0.564$ & ESJI (KZ) & $=8.716$ & IBI (India) & $=4.260$ \\
\hline & JIF & $=1.500$ & SJIF (Morocco & $=5.667$ & OAJI (USA) & $=0.350$ \\
\hline
\end{tabular}

учитывать не только свои возможности, но и наличие на рынке обуви аналогичного назначения конкурирующих предприятий, а также предпочтения покупателей в отдельных сегментах рынка.

Нельзя говорить о качестве или конкурентоспособности обуви вообще без учёта потребностей покупателей определённой группы на рынках соответствующего типа. Рынки обувных товаров представляют собой разнородную совокупность покупателей, имеющих различные вкусы и предпочтения.

Деятельность по выделению потенциальных групп потребителей конкретных видов товаров называется сегментацией рынка. Сегментация концентрируется на различиях в поведении разных типов покупателей (потребителей) на соответствующих рынках. Для обувных предприятий сегментация покупателей является основанием для корректировки существующей структуры ассортимента обуви или для разработки новых моделей [8].

Таким образом, сегментация рынков обуви является важной составляющей и началом работ по обеспечению конкурентоспособности современной обуви. Практическое её значение состоит в том, что конкретизация типов потребителей создаёт предпосылки для корректировки и обновления структуры и ассортимента обуви, совершенствования технологии и организации производства, гарантируя предприятиям устойчивое финансовое положение

В настоящее время резко увеличилось количество предприятий по внедрению системы менеджмента качества на основе стандартов ИСО серии 9000, чему способствуют ряд обстоятельств, основным из которых является

Статистические методы предусматривают сбор, систематизацию и математическую обработку результатов производственной деятельности, анализ информации для принятия корректирующих и предупреждающих мер, дальнейшее исследование объекта контроля для достижения приемлемого (оптимального) уровня качества.

Внедрение системы качества представляет собой комплекс работ, который затрагивает различные аспекты деятельности организации и ее подсистемы - подсистему стратегического управления, производственную подсистему, подсистему логистики, управление персоналом, внутренние коммуникации, документооборот и др. В связи с этим, внедрение системы качества является достаточно трудной, длительной и трудоемкой задачей. Решение этой задачи, как правило, происходит в несколько этапов.

Совершенствование СМК имеет смысл только в том случае, если у коллектива предприятия есть желание добиться весомых результатов в борьбе за качество своей продукции, но все это должно провоцировать желание коллектива достичь новых высот, двигаться вперед и гарантировать себе и своему предприятию стабильные результаты своей деятельности.[8]

Для реализации сформулированных процедур пожеланий должны быть выполнены следующие мероприятия, а именно:

*шаг 1 - осознание высшим руководством цели создания и внедрения СМК на предприятии; *шаг 2 - установление потребностей и ожиданий потребителей и других заинтересованных сторон;

*шаг 3 - формирование стратегии управления, Политики и Целей в области качества;

* шаг 4 - организация обучения в области качества всех сотрудников; СMK;

* шаг 5 - планирование работ по внедрению

* шаг 6 - внедрение СМК с формированием команды, состоящей из различных специалистов;

* шаг 7 - установление системы процессов, их согласованной взаимосвязи и взаимодействия, выделение ключевых процессов, необходимых для достижения целей в области качества;

* шаг 8 - документирование СМК (в том объеме и степени конкретизации, необходимом именно для вашей организации - не забывая об обязательности некоторой документации в соответствии с требованиями ИСО 9001-2015);

* шаг 9 - внутренние аудиты;

* шаг 10 - доработка документации СМК и устранение замечаний по результатам внутренних аудитов и отработки при внедрении в действие разработанной нормативной документации;

* шаг 11 - сертификация СМК;

* шаг 12 - дальнейшее развитие СМК.

Эффективность проектирования и разработки продукции зависит не только от используемого оборудования и программного обеспечения, но и от квалификации и профессионализма служащего в конструкторском бюро персонала.

Необходимо внедрить информацию о способе сведения к минимуму браков на производстве, реализуя семь обязательных шагов.

Для решения всевозможных проблемы, связанных с появлением брака, неполадками оборудования, увеличением времени от выпуска партии изделий до её сбыта, наличием на складе нереализованной продукции, поступлением рекламаций применяется диаграмма Парето.

Диаграмма Парето позволяет распределить усилия для разрешения возникающих проблем и установить основные факторы, с которых нужно начинать действовать с целью преодоления 


\begin{tabular}{|c|c|c|c|c|c|c|}
\hline \multirow{4}{*}{ Impact Factor: } & ISRA (India) & $=3.117$ & SIS (USA) & $=0.912$ & ICV (Poland) & $=6.630$ \\
\hline & ISI (Dubai, UAE & $=0.829$ & РИНЦ (Russia & $=\mathbf{0 . 1 5 6}$ & PIF (India) & $=1.940$ \\
\hline & GIF (Australia) & $=0.564$ & ESJI (KZ) & $=8.716$ & IBI (India) & $=4.260$ \\
\hline & JIF & $=1.500$ & SJIF (Morocco & $=5.667$ & OAJI (USA) & $=0.350$ \\
\hline
\end{tabular}

возникающих проблем, используя преимущества партисипативного управления, а именно:

1) повышение мотивации персонала;

2) сплочение коллектива;

3) повышение лояльности работников к предприятию;

4)ускорение развития и внедрения инноваций;

5)улучшение имиджа предприятия;

6)увеличение эффективности экономической деятельности.

И успех коллективу предприятия гарантирован

10. пунрк улучшения

В данном разделе ГОСТ Р ИСО 90012015 установлены требования к:

* проведению улучшений в продукции, услугах и процессах, а также СМК предприятия.

* действиям при обнаружении несоответствий, проведению корректирующих действий;

* непрерывному совершенствованию СМК и результатов деятельности предприятия.

Таким образом, ключевыми изменениями в новой версии стандарта являются требования по оценке рисков, а также подход, основанный на управлении рисками при проектировании и разработке системы менеджмента качества.

На АО «Шахтинский завод Гидропривод» г. Шахты Ростовской области внедрена система менеджмента качества, соответствующая требованиям международного стандарта ISO 9001. Сертификат соответствия системы менеджмента качества АО «ШЗГ» имеется.

Необходимо было внедрить информацию о способе сведения к минимуму браков на производстве., а именно:

Первый шаг. Составить таблицу с характеристикой всех случаев брака на предприятии. Для показательной статистики рекомендуется анализ данных минимум за год.

Второй шаг. Объединить аналогичные причины производственного брака в общую группу. Благодаря выделению группы схожих причин брака удастся рассчитать число случаев за период, также потери от них и пути их устранения.

Третий шаг. Проведение анализа. Обычно после группировки оказывается, что только несколько одинаковых причин регулярно повторяются, приводя к основной доле производственного брака. Именно они заслуживают первоочередного внимания.

Четвертый шаг - установить причину брака на предприятии с максимальным количеством случаев и наибольшими потерями.

Пятый шаг - снижать или исключать вероятность повторения частых причин производственного брака. В бережливом производстве существует термин пока-ёкэ (pokayoke, япон. - защита от ошибок). Данный термин предполагает: чтобы предотвратить производственный брак в будущем, требуется обеспечение таких условий, когда физически невозможно повторение брака, чтобы не было у сотрудника возможности повторной ошибки и пр.

Шестой шаг - разработка и введение в работу системы мотивации персонала, ориентированной на сокращение производственного брака. В числе возможных мер можно отметить определенный размер депремирования сотрудника за выпуск каждой тонны товаров с браком, либо при допущенных ошибках. Также могут выплачиваться премии за уменьшение доли брака до установленного норматива, индивидуальные показатели работников можно размещать на стендах - будет стимулировать желание работников сократить уровень брака.

Седьмой шаг - организация постоянного процесса повышения качества. Для каждого сотрудника нужно определить индивидуальные показатели качества. Как правило, достаточно 1-3 показателей, в рамках партисипативного управления.

Характеристика дефектов за 2017год приведена в таблице 1,a на рисунке8 -результаты исследований, характеризующие влияние этих дефектов на качество продукции. характеристика дефектов за 2018 год приведена в таблице 2, а диаграмма Парето выявленных дефектов -на рисунке 9

Таблица 1. Характеристика дефектов, выявленные на АО «ШЗГ» за 2017 год

\begin{tabular}{|c|c|c|c|}
\hline & $\begin{array}{c}\text { Число } \\
\text { обнаруженных } \\
\text { дефектов }\end{array}$ & $\begin{array}{c}\text { Суммарное } \\
\text { числопо } \\
\text { обнаружений }\end{array}$ & $\begin{array}{c}\text { дефектов, } \\
\text { \% }\end{array}$ \\
\hline Дефект & 78 & $16,5 \%$ & $16 \%$ \\
\hline Брак шайбы & 74 & $15,6 \%$ & $32 \%$ \\
\hline Брак блока & 70 & $14,8 \%$ & $47 \%$ \\
\hline Брак корпуса & & & 4 \\
\hline
\end{tabular}




\begin{tabular}{|c|c|c|c|c|c|c|}
\hline \multirow{4}{*}{ Impact Factor: } & ISRA (India) & $=3.117$ & SIS (USA) & $=0.912$ & ICV (Poland) & $=6.630$ \\
\hline & ISI (Dubai, UAE & $=0.829$ & РИНЦ (Russia) & $=0.156$ & PIF (India) & $=1.940$ \\
\hline & GIF (Australia) & $=0.564$ & ESJI (KZ) & $=8.716$ & IBI (India) & $=4.260$ \\
\hline & JIF & $=1.500$ & SJIF (Morocco) & $=5.667$ & OAJI (USA) & $=0.350$ \\
\hline
\end{tabular}

\begin{tabular}{|c|c|c|c|} 
Обломан палец & 64 & $13,5 \%$ & $60 \%$ \\
\hline Разрушение поршневого кольца & 57 & $12,1 \%$ & $73 \%$ \\
\hline Раскрылся распределитель & 54 & $11,4 \%$ & $84 \%$ \\
\hline Обрыв поршня шатуна & 32 & $6,8 \%$ & $91 \%$ \\
\hline Задиры на распределителе & 30 & $6,3 \%$ & $97 \%$ \\
\hline Прочие дефекты & 14 & $3,0 \%$ & $100 \%$ \\
\hline Итого & 473 & & \\
\hline
\end{tabular}

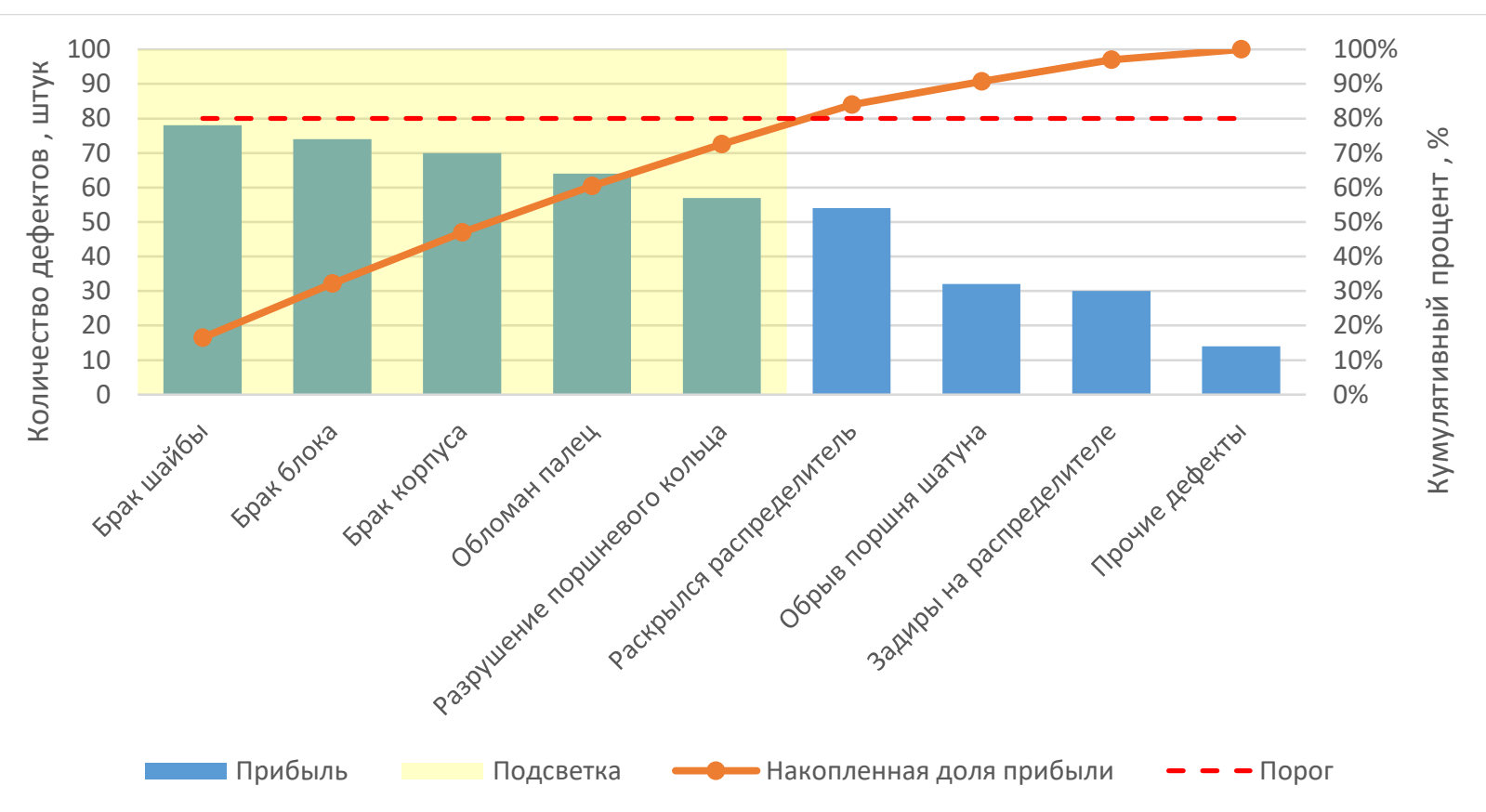

Рисунок 8 - Диаграмма Парето выявленных дефектов на АО «ШЗГ» за 2017 год.

Таблица 2 - Характеристика дефектов, выявленные на АО «ШЗГ» за 2018 год.

\begin{tabular}{|c|c|c|c|}
\hline Дефект & $\begin{array}{c}\text { Число } \\
\text { обнаружений }\end{array}$ & $\begin{array}{c}\text { Накопленная доля } \\
\text { обнаружений }\end{array}$ & Суммарно \\
\hline Задиры на распределителе & 27 & $12,4 \%$ & $12 \%$ \\
\hline Брак шайбы & 23 & $12,4 \%$ & $25 \%$ \\
\hline Обрыв поршня шатуна & 22 & $11,9 \%$ & $37 \%$ \\
\hline Раскрылся распределитель & 21 & $11,3 \%$ & $48 \%$ \\
\hline Брак корпуса & 20 & $11,3 \%$ & $59 \%$ \\
\hline Брак блока & 19 & $11,3 \%$ & $71 \%$ \\
\hline Обломан палец & 18 & $10,3 \%$ & $81 \%$ \\
\hline Разрушение поршневого кольца & 17 & $9,8 \%$ & $91 \%$ \\
\hline Прочие дефекты & 8 & $9,3 \%$ & $100 \%$ \\
\hline Итого & 27 & & \\
\hline
\end{tabular}




\begin{tabular}{|c|c|c|c|c|c|c|}
\hline \multirow{4}{*}{ Impact Factor: } & ISRA (India) & $=3.117$ & SIS (USA) & $=0.912$ & ICV (Poland) & $=6.630$ \\
\hline & ISI (Dubai, UAE & $=0.829$ & РИНЦ (Russia) & $=0.156$ & PIF (India) & $=1.940$ \\
\hline & GIF (Australia) & $=0.564$ & ESJI (KZ) & $=8.716$ & IBI (India) & $=4.260$ \\
\hline & JIF & $=1.500$ & SJIF (Morocco) & $=5.667$ & OAJI (USA) & $=0.350$ \\
\hline
\end{tabular}

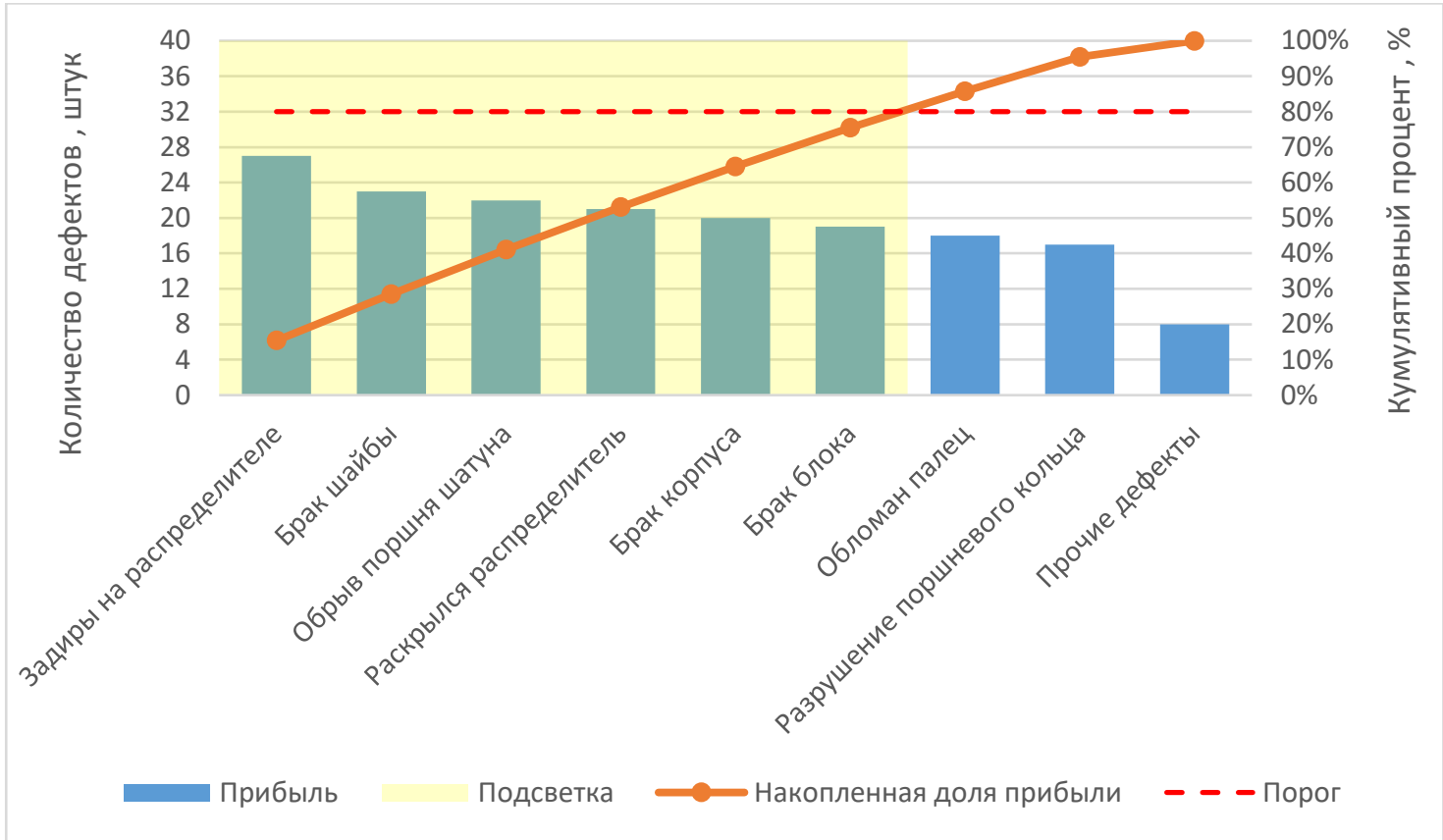

Рисунок 9 - Диаграмма Парето выявленных дефектов на АО «ШЗГ» за 2018 год

Для осуществления анализа качества услуг ООО «Завод «Техмаш» необходима определенная информационная база. Источниками информации являются данные, полученные отделом маркетинга в ходе исследований внешней среды предприятия.

Неудовлетворительные результаты исследования качества выпускаемой продукции на ООО «Завод Техмаш» спровоцировало необходимость сформировать цели и задачи в рамках СМК для того, чтобы существенно улучшить качество выпускаемой пр.» производит машины непрерывного транспорта (конвейернотранспортёрная техника), сельскохозяйственную почвообрабатывающую технику, оборудование для транспортировки, хранения и переработки зерно продуктов (элеваторы, ХПП, сахарные заводы), профильные трубы.. Характеристика дефектов за 2017 год приведена в таблице 3, диаграмма Парето выявленных дефектов приведена на рисунке 10. Характеристика же выявленных дефектов за 2018 год приведена в таблице 4, а диаграмма Парето приведена - на рисунке 11.

Таблица 3. - Характеристика дефектов, выявленные на ООО «Завод «Техмаш» за 2017 год

\begin{tabular}{|c|c|c|c|}
\hline $\begin{array}{c}\text { Наименование дефектов } \\
\text { выявленные у } \\
\text { реализованных машин }\end{array}$ & $\begin{array}{c}\text { Число обнаруженных } \\
\text { дефектов у } \\
\text { реализованных машин }\end{array}$ & $\begin{array}{c}\text { Накопленная } \\
\text { доля } \\
\text { обнаруженных } \\
\text { дефектов }\end{array}$ & $\begin{array}{c}\text { Суммарное число } \\
\text { обнаруженных дефектов } \\
\text { (кумулятивный } \\
\text { процент) }\end{array}$ \\
\hline Брак подшипника & $17 / 8$ & $38 \%$ & $38 \%$ \\
\hline $\begin{array}{l}\text { Заклинивание дисков } \\
\text { вращения }\end{array}$ & $9 / 5$ & $20 \%$ & $58 \%$ \\
\hline $\begin{array}{ll}\text { Нарушение } & \text { технологии } \\
\text { закалки детали } & \end{array}$ & $5 / 3$ & $11 \%$ & $69 \%$ \\
\hline Деформация рамы & $4 / 4$ & $9 \%$ & $78 \%$ \\
\hline Трещина Диска & $3 / 3$ & $6 \%$ & $84 \%$ \\
\hline Прочие & $7 / 8$ & $16 \%$ & $100 \%$ \\
\hline Итого & $45 / 11$ & $100 \%$ & \\
\hline
\end{tabular}




\begin{tabular}{|c|c|c|c|c|c|c|}
\hline \multirow{4}{*}{ Impact Factor: } & ISRA (India) & $=3.117$ & SIS (USA) & $=0.912$ & ICV (Poland) & $=6.630$ \\
\hline & ISI (Dubai, UAE & $=0.829$ & РИНЦ (Russia & $=\mathbf{0 . 1 5 6}$ & PIF (India) & $=1.940$ \\
\hline & GIF (Australia) & $=0.564$ & ESJI (KZ) & $=8.716$ & IBI (India) & $=4.260$ \\
\hline & JIF & $=1.500$ & SJIF (Morocco & $=5.667$ & OAJI (USA) & $=0.350$ \\
\hline
\end{tabular}

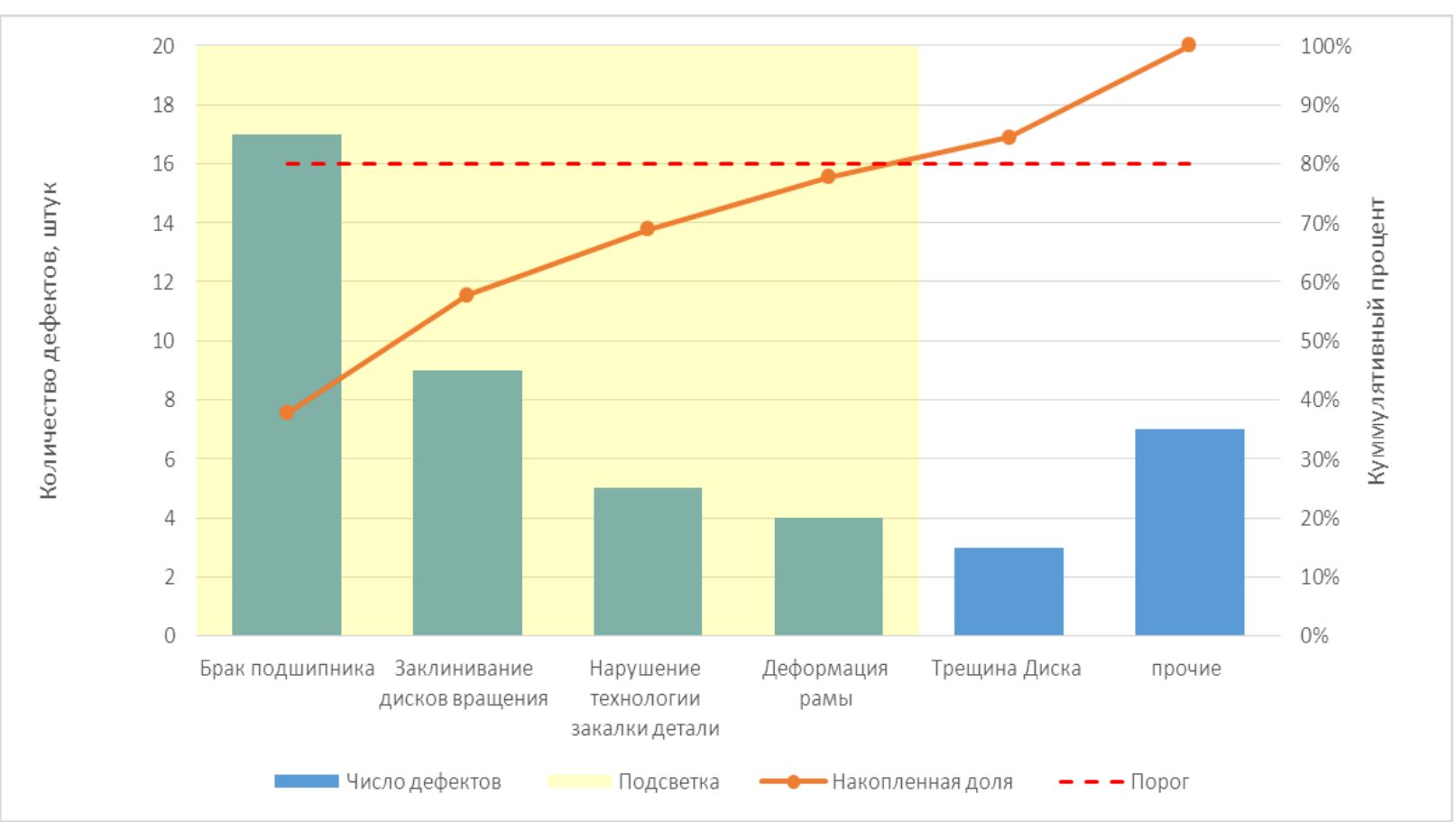

Рисунок 10- Диаграмма Парето выявленных дефектов на ООО, «Завод «Техмаш» за 2017 год

Таблица 4. - Характеристика дефектов, выявленные на ООО «Завод «Техмаш» за 2018 год

\begin{tabular}{|c|c|c|c|}
\hline $\begin{array}{c}\text { Наименование } \\
\text { дефектов } \\
\text { выявленные у } \\
\text { реализованных } \\
\text { машин }\end{array}$ & $\begin{array}{c}\text { Число обнаруженных } \\
\text { дефектов у } \\
\text { реализованных } \\
\text { машин }\end{array}$ & $\begin{array}{c}\text { Накопленная доля } \\
\text { обнаруженных } \\
\text { дефектов }\end{array}$ & $\begin{array}{c}\text { Суммарное число } \\
\text { обнаруженных } \\
\text { дефектов } \\
\text { (кумулятивный } \\
\text { процент) }\end{array}$ \\
\hline $\begin{array}{c}\text { Заклинивание дисков } \\
\text { вращения }\end{array}$ & $4 / 4$ & $31 \%$ & $31 \%$ \\
\hline $\begin{array}{c}\text { Нарушение технологии } \\
\text { закалки детали }\end{array}$ & $3 / 3$ & $23 \%$ & $54 \%$ \\
\hline $\begin{array}{c}\text { Деформация рамы } \\
\text { Деформация оси колеса }\end{array}$ & $2 / 3$ & $15 \%$ & $69 \%$ \\
\hline Трещина Диска & $2 / 2$ & $15 \%$ & $84 \%$ \\
\hline Прочие & $1 / 1$ & $8 \%$ & $8 \%$ \\
\hline Итого & $1 / 1$ & $8 \%$ & $100 \%$ \\
\hline
\end{tabular}




\begin{tabular}{|c|c|c|c|c|c|c|}
\hline \multirow{4}{*}{ Impact Factor: } & ISRA (India) & $=3.117$ & SIS (USA) & $=0.912$ & ICV (Poland) & $=6.630$ \\
\hline & ISI (Dubai, UAE & $=0.829$ & РИНЦ (Russia & $=0.156$ & PIF (India) & $=1.940$ \\
\hline & GIF (Australia) & $=0.564$ & ESJI (KZ) & $=8.716$ & IBI (India) & $=4.260$ \\
\hline & JIF & $=1.500$ & SJIF (Morocce & $=5.667$ & OAJI (USA) & $=0.350$ \\
\hline
\end{tabular}

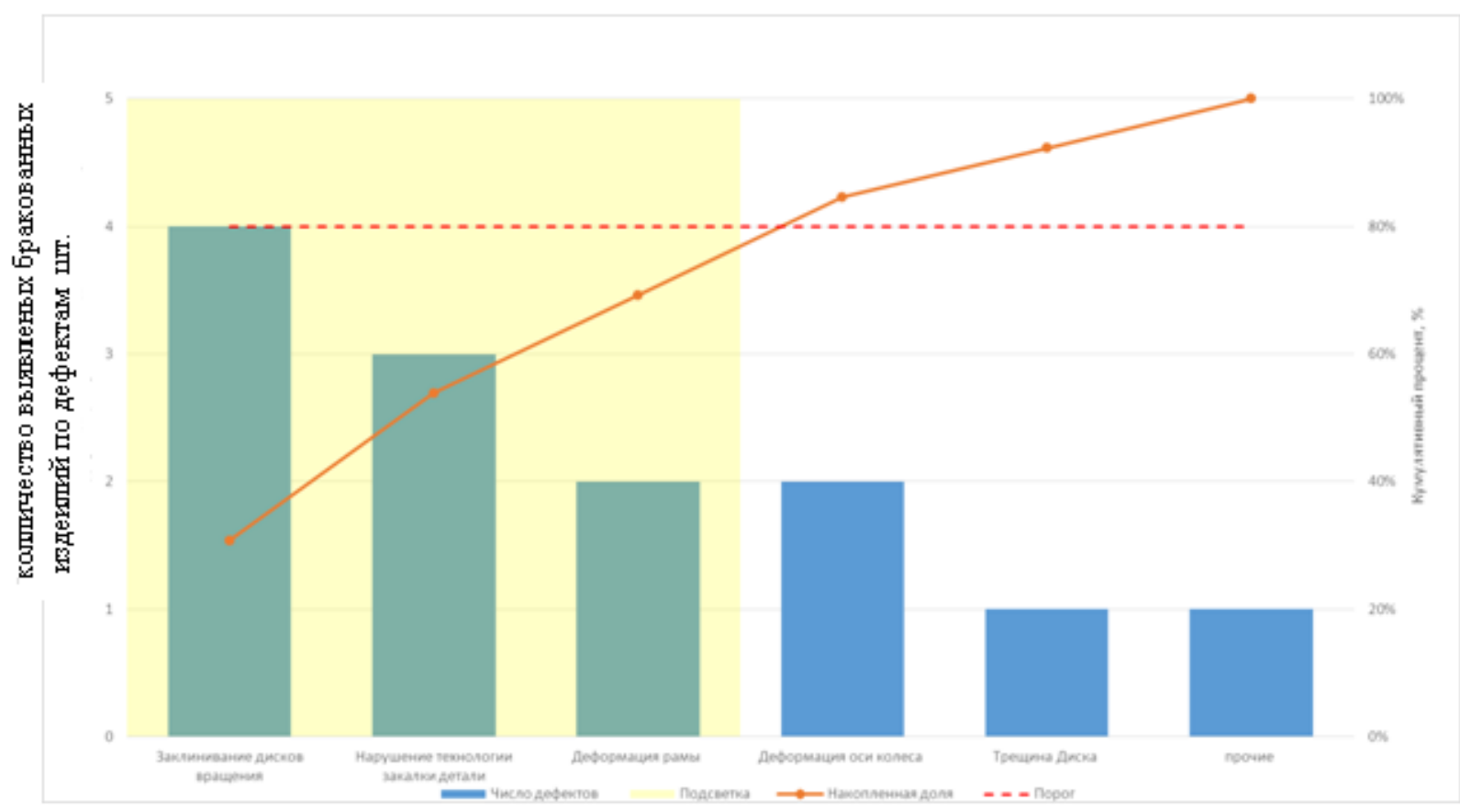

Рисунок 11 - Диаграмма Парето выявленных дефектов на ООО «Завод «Техмаш » за 2018 год

Опыт применения ими статистических методов контроля качества с использованием диаграммы Парето подтвердил их эффективность для разработки мероприятий предприятиями, чтобы существенно улучшить качество своей продукции, гарантируя своим потребителям безопасность и её востребованность.

Разработанное авторами программное обеспечение для обработки результатов статистических методов контроля качества с использованием диаграммы Парето осуществляет им достоверность и гарантирует предприятиям обеспечить своей продукции импортозамещение и востребованность.

Качество формируется в процессе производства продукции, следовательно, главным фактором обеспечения качества и одним из решающих элементов обеспечения конкурентоспособности предприятия является действующая на предприятия система менеджмента качества.

Поводом для разработки СМК служит осознание новых реалий рынка.

В сентябре 2015 года вступил в силу международный стандарт ISO 9001:2015. Российская версия стандарта ГОСТ Р ИСО 9001-2015 «Системы менеджмента качества. Требования» вступила в силу с 01 ноября 2015 года.

В новой версии стандарта ГОСТ Р ИСО 9001-2015 относительно предыдущей внесены значительные изменения, в частности, изменилась структура стандарта. В новой версии стандарта вместо 9 теперь представлено 10 разделов., который сформирован как улучшение

В данном разделе ГОСТ Р ИСО 90012015 установлены требования к:

* проведению улучшений в продукции, услугах и процессах, а также СМК предприятия.

* действиям при обнаружении несоответствий, проведению корректирующих действий;

* непрерывному совершенствованию СМК и результатов деятельности предприятия.

Среди статистических методов контроля качества наиболее распространены как сегодня, так и завтра, так называемые семь инструментов контроля качества :

* диаграмма Парето;

* причинно-следственная диаграмма

Исикавы;

* контрольная карта;

* гистограмма;

* диаграмма разброса;

* метод расслоения;

* контрольные листки.

Диаграмма Парето позволяет наглядно представить величину потерь дефектов в зависимости от различных объектов, представляет собой разновидность столбиковой диаграммы, применяемой для наглядного отображения рассматриваемых факторов в порядке уменьшения их значимости. 


\begin{tabular}{|c|c|c|c|c|c|c|}
\hline \multirow{4}{*}{ Impact Factor: } & ISRA (India) & $=3.117$ & SIS (USA) & $=0.912$ & ICV (Poland) & $=6.630$ \\
\hline & ISI (Dubai, UAE & $=0.829$ & РИНЦ (Russia & $=0.156$ & PIF (India) & $=1.940$ \\
\hline & GIF (Australia) & $=0.564$ & ESJI (KZ) & $=8.716$ & IBI (India) & $=4.260$ \\
\hline & JIF & $=1.500$ & SJIF (Morocco & $=\mathbf{5 . 6 6 7}$ & OAJI (USA) & $=0.350$ \\
\hline
\end{tabular}

Предприятия металлургической отрасли России активно включились в работу по разработке, внедрению и сертификации систем качества на соответствие международным стандартам ИСО серии 9000. Для этой отрасли характерны проблемы, существующие в настоящее время во всех отраслях экономики страны а именно, в связи со значительным спадом производства снизилось использование производственных мощностей.

В качестве объекта производства выбрана поковка прямоугольного сечения, изготовленная из углеродистой стали методом свободной ковки и с применением подкладных штампов на ОАО «НЛМК». Внешний вид поковки представлен на рисунке 12

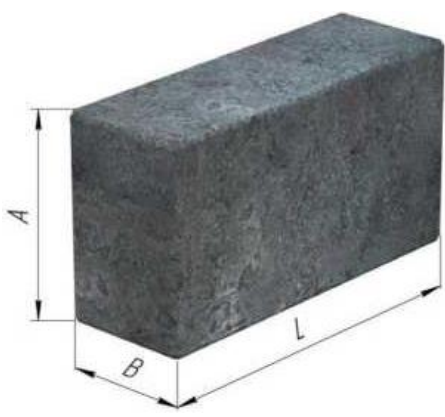

Рисунок 12- Поковка прямоугольного сечения: $A$ - высота, мм; $B$ - ширина, мм; $L$ - длина, мм.

Поковки изготавливаются в соответствии с ГОСТ 8479-70 «Поковки из конструкционной углеродистой и легированной стали. Общие технические условия».

Поковки применяются для изготовления деталей механизмов и запасных частей металлургического, горнодобывающего и машиностроительного оборудования: штанги засыпных аппаратов доменных печей, бандажные кольца, вал-шестерни, зубчатые и крановые колеса, ролики $\mathrm{MH} / 13$, металлорежущие ножи и Т.П.

Число обнаруженных дефектов у поковки за 2017 год приведено в таблице 5, а на рисунке 13, построенная диаграмма Парето для выявленных дефектов за 2017 год, ожидаемое число дефектов в 2018 году приведено в таблице _6_, а построенная диаграмма Парето на рисунке $\overline{14}$

Таблица 5 - Характеристика дефектов поковки, выявленные на ОАО «НЛМК» за 2017 год

\begin{tabular}{|c|c|c|c|}
\hline $\begin{array}{c}\text { Наименование } \\
\text { дефектов выявленные } \\
\text { у поковки }\end{array}$ & $\begin{array}{c}\text { Число обнаруженных } \\
\text { дефектов у } \\
\text { поковки }\end{array}$ & $\begin{array}{c}\text { Накопленная доля } \\
\text { обнаруженных } \\
\text { дефектов у поковки }\end{array}$ & $\begin{array}{c}\text { Суммарное число } \\
\text { обнаруженных } \\
\text { дефектов } \\
\text { у поковки } \\
\text { (кумулятивый } \\
\text { процент) }\end{array}$ \\
\hline Недогрев & 15200 & $15 \%$ & $15 \%$ \\
\hline Пережёг & 13600 & $14 \%$ & $29 \%$ \\
\hline Ослабление размера & 12800 & $13 \%$ & $42 \%$ \\
\hline Отклонение по длине & 10500 & $10 \%$ & $52 \%$ \\
\hline Вогнутые торцы & 9700 & $10 \%$ & $62 \%$ \\
\hline Наружные трещины или & 8300 & $8 \%$ & $70 \%$ \\
\hline вранины & & & \\
\hline
\end{tabular}




\begin{tabular}{|c|c|c|c|c|c|c|}
\hline \multirow{4}{*}{ Impact Factor: } & ISRA (India) & $=3.117$ & SIS (USA) & $=0.912$ & ICV (Poland) & $=6.630$ \\
\hline & ISI (Dubai, UAE & $=0.829$ & РИНЦ (Russia) & $=0.156$ & PIF (India) & $=1.940$ \\
\hline & GIF (Australia) & $=0.564$ & ESJI (KZ) & $=8.716$ & IBI (India) & $=4.260$ \\
\hline & JIF & $=1.500$ & SJIF (Morocco) & $=5.667$ & OAJI (USA) & $=0.350$ \\
\hline
\end{tabular}

\begin{tabular}{|c|c|c|c|}
\hline Внутренние разрывы & 7200 & $7 \%$ & $77 \%$ \\
\hline Недостаточный уков & 6400 & $6 \%$ & $83 \%$ \\
\hline Вмятины & 5600 & $6 \%$ & $89 \%$ \\
\hline $\begin{array}{c}\text { Не выдержаны } \\
\text { геоетрические размеры } \\
\text { поковки }\end{array}$ & 4800 & $5 \%$ & $94 \%$ \\
\hline Перекос & 3850 & $4 \%$ & $98 \%$ \\
\hline Прочее & 2050 & $2 \%$ & $100 \%$ \\
\hline Итого & 100000 & & \\
\hline
\end{tabular}

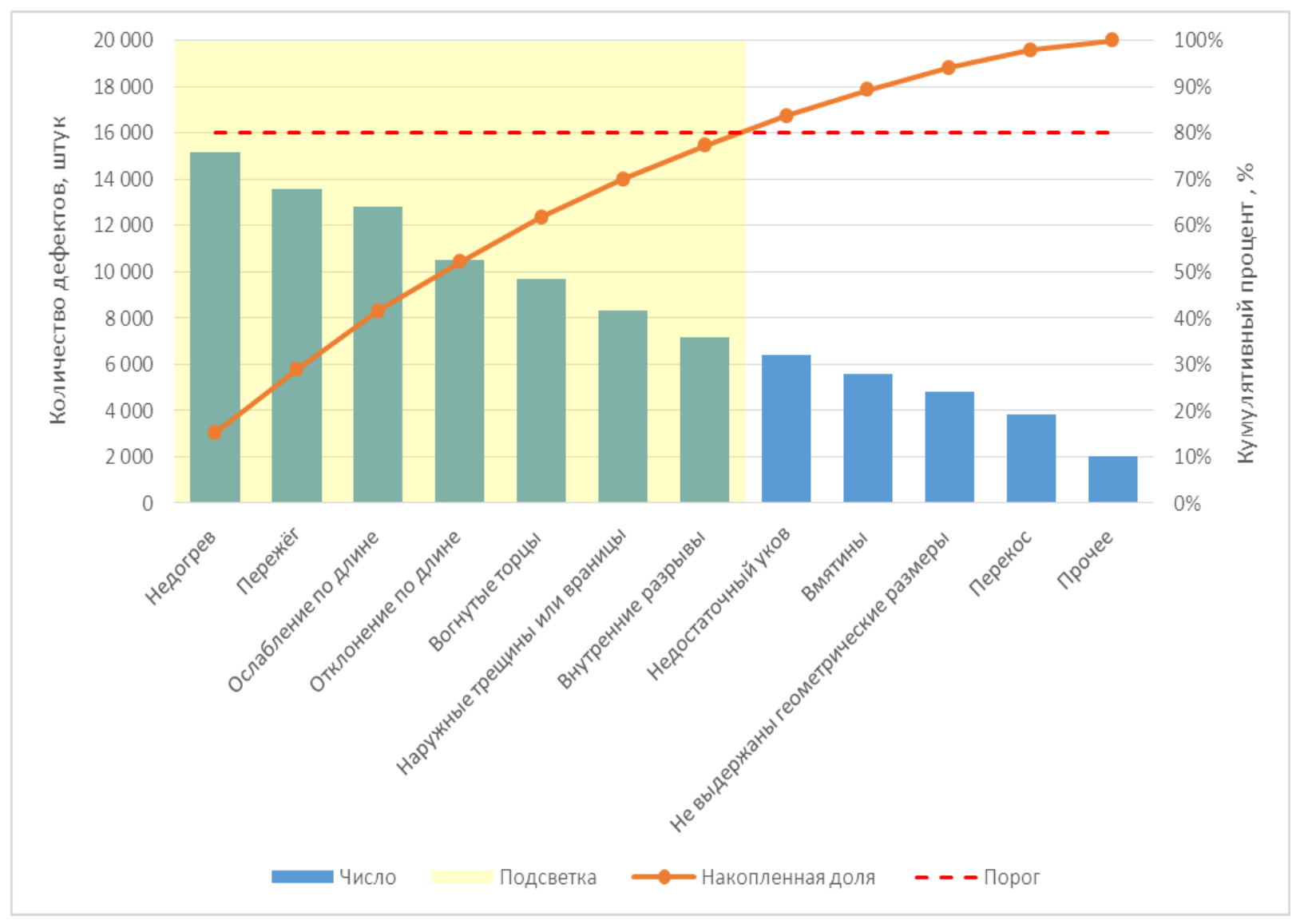

Рисунок 13 - Диаграмма Парето выявленных дефектов поковки на ОАО «НЛМК» за 2017 год 


\begin{tabular}{|c|c|c|c|c|c|c|}
\hline \multirow{4}{*}{ Impact Factor: } & ISRA (India) & $=3.117$ & SIS (USA) & $=0.912$ & ICV (Poland) & $=6.630$ \\
\hline & ISI (Dubai, UAE & $=0.829$ & РИНЦ (Russia & $=0.156$ & PIF (India) & $=1.940$ \\
\hline & GIF (Australia) & $=0.564$ & ESJI (KZ) & $=8.716$ & IBI (India) & $=4.260$ \\
\hline & JIF & $=1.500$ & SJIF (Morocce & $=5.667$ & OAJI (USA) & $=0.350$ \\
\hline
\end{tabular}

Таблица 6 - Характеристика дефектов, выявленных у поковки на ОАО «НЛМК» за 2018 год

\begin{tabular}{|c|c|c|}
\hline $\begin{array}{l}\text { Наименование дефектов } \\
\text { выявленные у поковки }\end{array}$ & $\begin{array}{c}\text { Число обнаруженных } \\
\text { дефектов у } \\
\text { поковки }\end{array}$ & $\begin{array}{c}\text { Суммарное число обнаруженных дефектов } \\
\text { у поковки } \\
\text { (кумулятивный процент) }\end{array}$ \\
\hline калина & 1510 & $19 \%$ \\
\hline Іерегрев & 1430 & $36 \%$ \\
\hline ажимы & 1300 & $49 \%$ \\
\hline ривизна & 1180 & $60 \%$ \\
\hline $\begin{array}{l}\text { Ie } \quad \text { выдержаны показатели } \\
\text { rexанических свойств поковки }\end{array}$ & 1170 & $69 \%$ \\
\hline мятины & 1110 & $76 \%$ \\
\hline абоены & 1050 & $82 \%$ \\
\hline Іом-бой & 1000 & $87 \%$ \\
\hline Іе заполненные фигуры & 930 & $90 \%$ \\
\hline Іедоштамповка & 900 & $92 \%$ \\
\hline ривизна & 880 & $94 \%$ \\
\hline Ірочее & 410 & $100 \%$ \\
\hline Ітого & 12870 & \\
\hline
\end{tabular}

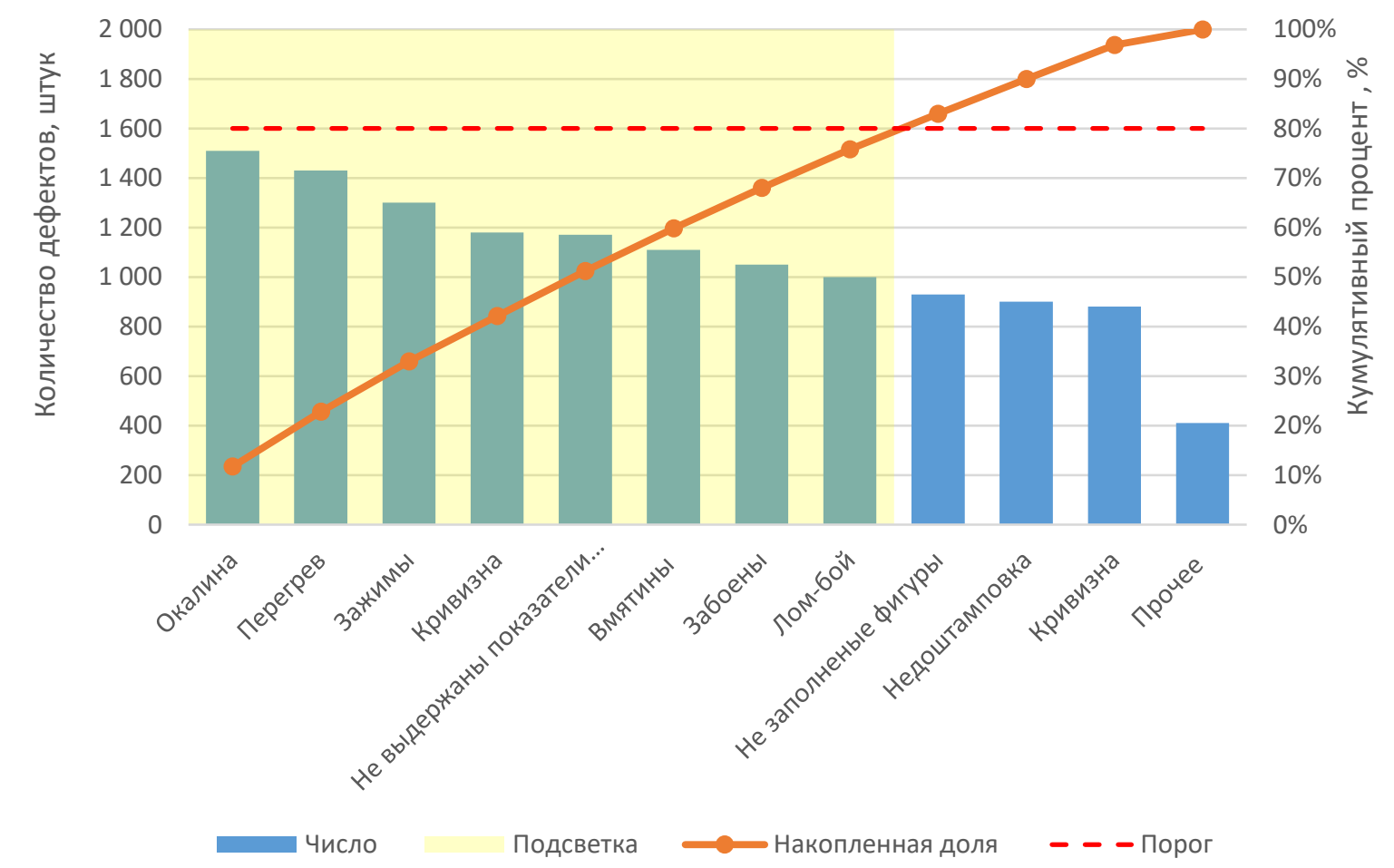

Рисунок 14 - Диаграмма Парето выявленных дефектов у поковки на ОАО «НЛМК» за 2018 год 


\begin{tabular}{|c|c|c|c|c|c|c|}
\hline \multirow{4}{*}{ Impact Factor: } & ISRA (India) & $=3.117$ & SIS (USA) & $=0.912$ & ICV (Poland) & $=6.630$ \\
\hline & ISI (Dubai, UAE & $=0.829$ & РИНЦ (Russia & $=\mathbf{0 . 1 5 6}$ & PIF (India) & $=1.940$ \\
\hline & GIF (Australia) & $=0.564$ & ESJI (KZ) & $=8.716$ & IBI (India) & $=4.260$ \\
\hline & JIF & $=1.500$ & SJIF (Morocco & $=5.667$ & OAJI (USA) & $=0.350$ \\
\hline
\end{tabular}

Опыт применения статистических методов контроля качества с использованием диаграммы Парето подтвердил их эффективность для разработки мероприятий предприятиями, что бы существенно улучшить качество своей продукции, гарантируя своим потребителям безопасность и её востребованность.

Разработанное авторами программное обеспечение для обработки результатов статистических методов контроля качества с использованием диаграммы Парето создаёт основу для их достоверности и гарантирует предприятиям обеспечивать своей продукции импортозамещение востребованность.

Современная рыночная экономика предъявляет принципиально новые требования к качеству выпускаемой продукции. Управление качеством является одной из ключевых функций как корпоративного, так и проектного менеджмента, основным средством достижения и поддержания конкурентоспособности любого предприятия. Ключевой задачей менеджмента компаний является создание, практическая реализация и последующая сертификация системы менеджмента качества (современный термин, заменивший ранее использовавшийся термин - «системы управления качеством»), и поставляемой продукции в течение определённого периода времени (действия контракта, срока выпуска продукции данного вида и т.д.). Управление качеством является, по существу, сквозным аспектом системы управления

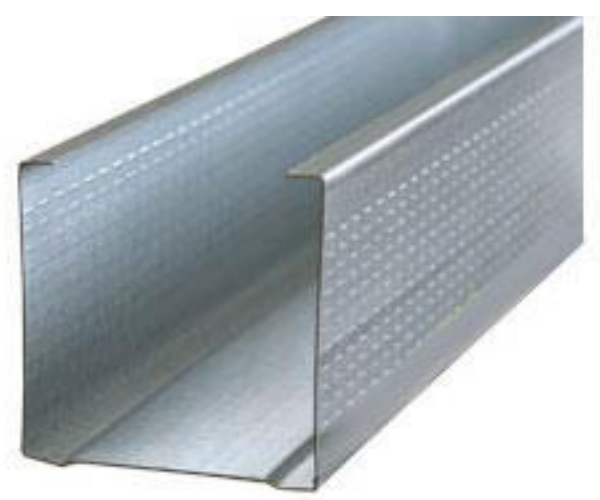

предприятием - аналогичным таким, как время, затраты, управление персоналом.[9]

Качество формируется в процессе производства продукции, следовательно, главным фактором обеспечения качества и одним из решающих элементов обеспечения конкурентоспособности предприятия является действующая на предприятии система менеджмента качества.

Основной вид деятельности ООО «МеталлСтрой»: производство строительных металлических конструкций, изделий и их частей.

Ассортимент выпускаемой продукции на ООО «Металл - Строй » очень разнообразен, он включает в себя стоечный, направляющий, потолочный, угловой профиль для гипсокартона, которые применяется для основных вертикальных стоек в гипсокартонных конструкциях. Стоечный профиль изготавливается путем прокатывания стальных лент через профилегибочный станок. Стандартный размер готовой продукции $300 \mathrm{~cm}$, при заказе нестандартной продукции профиль может иметь длину 350, 400см.( рисунок 15)

Стоечный профиль имеет три вида размеров в зависимости от области применения.

Профиль стоечный 50*50мм имеет небольшой размер стенки, что позволяет использовать его в небольших помещениях для выравнивания стен или скрытия проводов (рисунки 15).

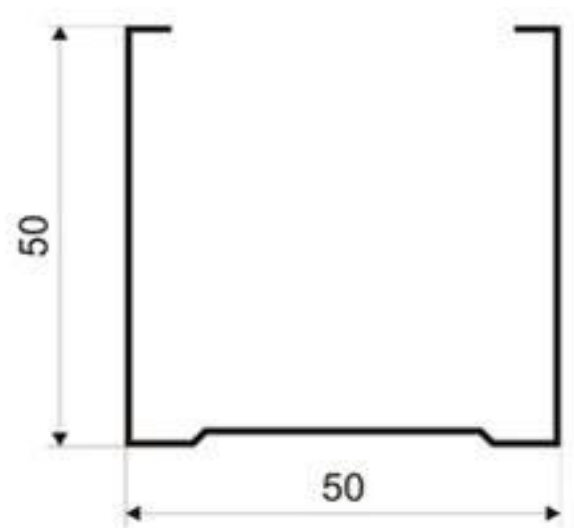

\section{Рисунок 15 - Профиль стоечный 50*50мм}

Армирующий профиль необходим для придания жесткости оконной конструкции и укрепления конструкции при эксплуатационных нагрузках.

ООО «Металл - Строй » выпускает армирующий профиль в ассортименте, различных видов, размеров, толщин. Армирующий профиль производится методом холодной катки из оцинкованной стали соответствующей всем установленным требованиям. Толщина армирующего профиля колеблется от 1,2 до 2,0мм.

На ООО «Металл - Строй» руководство по качеству является основным определяющим документом системы менеджмента качества и описывающим ее в соответствии с требованиями ГОСТ Р ИСО 9001: 2015.

Руководство по качеству направлено на применение «процессного подхода» при 


\begin{tabular}{|c|c|c|c|c|c|c|}
\hline \multirow{4}{*}{ Impact Factor: } & ISRA (India) & $=3.117$ & SIS (USA) & $=0.912$ & ICV (Poland) & $=6.630$ \\
\hline & ISI (Dubai, UAE & $=0.829$ & РИНЦ (Russia & $=0.156$ & PIF (India) & $=1.940$ \\
\hline & GIF (Australia) & $=0.564$ & ESJI (KZ) & $=8.716$ & IBI (India) & $=4.260$ \\
\hline & JIF & $=1.500$ & SJIF (Morocco & $=5.667$ & OAJI (USA) & $=0.350$ \\
\hline
\end{tabular}

разработке, внедрении и улучшении результативности системы менеджмента качества c целью повышения удовлетворенности потребителей путем выполнения их требований.

Система менеджмента качества предприятия предназначена для решения следующих основных задач:

- - обеспечения качества разрабатываемой и выпускаемой продукции, которая удовлетворяет требования потребителя;

- - обеспечения заказчику уверенности в соответствии разрабатываемой и выпускаемой продукции требованиям стандартов, ТЗ, ТУ, контрактам на проведение разработок и производство продукции;

- - улучшения деятельности предприятия для повышения качества разрабатываемой и выпускаемой продукции и предупреждения появления несоответствий характеристик продукции заданным требованиям;

- - стабильный уровень качества выпускаемой продукции и технологических процессов ее изготовления;

- - проведение на выполняемых стадиях жизненного цикла продукции взаимосвязанных организационно-технических мероприятий по обеспечению качества;

- - выполнение мероприятий по защите государственной тайны.

Диаграмма Парето позволяет распределить усилия для разрешения возникающих проблем и установить основные факторы, с которых нужно начинать действовать с целью преодоления возникающих проблем.

В таблицах 7 представлены данные о дефектах выявленные за 2017 год, а в таблице 8число дефектов за 2018 год.

Таблица 7 - Характеристика дефектов, выявленные на ООО «Металл - Строй» за 2017 год

\begin{tabular}{|l|c|c|c|}
\hline \multicolumn{1}{|c|}{ Дефект } & Число дефектов & $\begin{array}{c}\text { Накопленная доля } \\
\text { дефектов, \% }\end{array}$ & Кумулятивный процент, \% \\
\hline 1 & 2 & 3 & 4 \\
\hline Скручивание & 70 & 35,00 & 35,00 \\
\hline Выпуклость, вогнутость & 50 & 25,00 & 60,00 \\
\hline Отклонение от формы & 18 & 9,00 & 69,00 \\
\hline Кривизна & 15 & 7,50 & 76,50 \\
\hline Непровары & 12 & 6,00 & 82,50 \\
\hline Коррозия & 9 & 4,50 & 87,00 \\
\hline Заусенцы & 5 & 2,50 & 89,50 \\
\hline Разнотолщинность & 3 & 1,50 & 91,00 \\
\hline Отклонение от прямого угла & 2 & 1,00 & 92,00 \\
\hline Прочие & 16 & 8,00 & 100 \\
\hline Итого & 200 & - & - \\
\hline
\end{tabular}

На рисунке 16 представлена диаграмма Парето характеризующая дефекты, выявленные на ООО «Металл Строй» за 2017 год. 


\begin{tabular}{|c|c|c|c|c|c|c|}
\hline \multirow{4}{*}{ Impact Factor: } & ISRA (India) & $=3.117$ & SIS (USA) & $=0.912$ & ICV (Poland) & $=6.630$ \\
\hline & ISI (Dubai, UAE & $=0.829$ & РИНЦ (Russia & $=\mathbf{0 . 1 5 6}$ & PIF (India) & $=1.940$ \\
\hline & GIF (Australia) & $=0.564$ & ESJI (KZ) & $=8.716$ & IBI (India) & $=4.260$ \\
\hline & JIF & $=1.500$ & SJIF (Morocco & $=5.667$ & OAJI (USA) & $=0.350$ \\
\hline
\end{tabular}

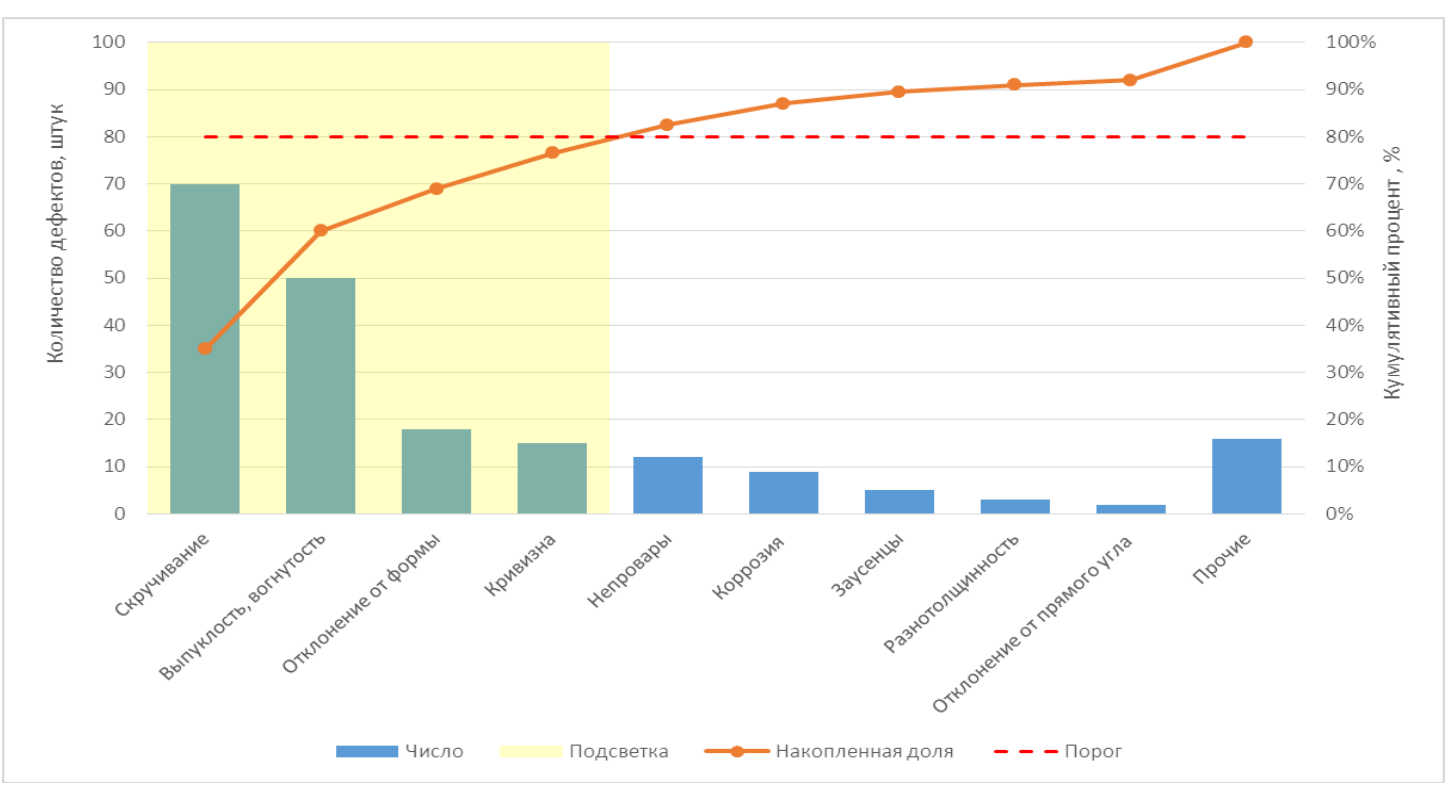

Рисунок 16 - Диаграмма Парето выявленных дефектов на ООО «Металл- Строй» за 2017 год

Таблица 8- Характеристика дефектов, выявленные на ООО «Металл - Строй» за 2018 год

\begin{tabular}{|l|c|c|c|}
\hline \multicolumn{1}{|c|}{ Дефект } & Число дефектов & $\begin{array}{c}\text { Накопленная доля } \\
\text { дефектов, \% }\end{array}$ & Кумулятивный процент, \% \\
\hline 1 & 2 & 3 & 4 \\
\hline Скручивание & 25 & 31,25 & 51,25 \\
\hline Выпуклость, вогнутость & 20 & 25,00 & 68,75 \\
\hline Отклонение от формы & 10 & 12,50 & 81,25 \\
\hline Кривизна & 10 & 12,50 & 87,5 \\
\hline Непровары & 5 & 6,25 & 90,00 \\
\hline Разнотолщинность & 2 & 2,50 & 91,25 \\
\hline Отклонение от прямого угла & 1 & 1,25 & 100 \\
\hline Прочие & 7 & 8,75 & - \\
\hline Итого & 80 & - & \\
\hline
\end{tabular}




\begin{tabular}{|c|c|c|c|c|c|c|}
\hline \multirow{4}{*}{ Impact Factor: } & ISRA (India) & $=3.117$ & SIS (USA) & $=0.912$ & ICV (Poland) & $=6.630$ \\
\hline & ISI (Dubai, UAI & $=0.829$ & РИНЦ (Russia & $=0.156$ & PIF (India) & $=1.940$ \\
\hline & GIF (Australia) & $=0.564$ & ESJI (KZ) & $=8.716$ & IBI (India) & $=4.260$ \\
\hline & JIF & $=1.500$ & SJIF (Morocce & $=5.667$ & OAJI (USA) & $=0.350$ \\
\hline
\end{tabular}

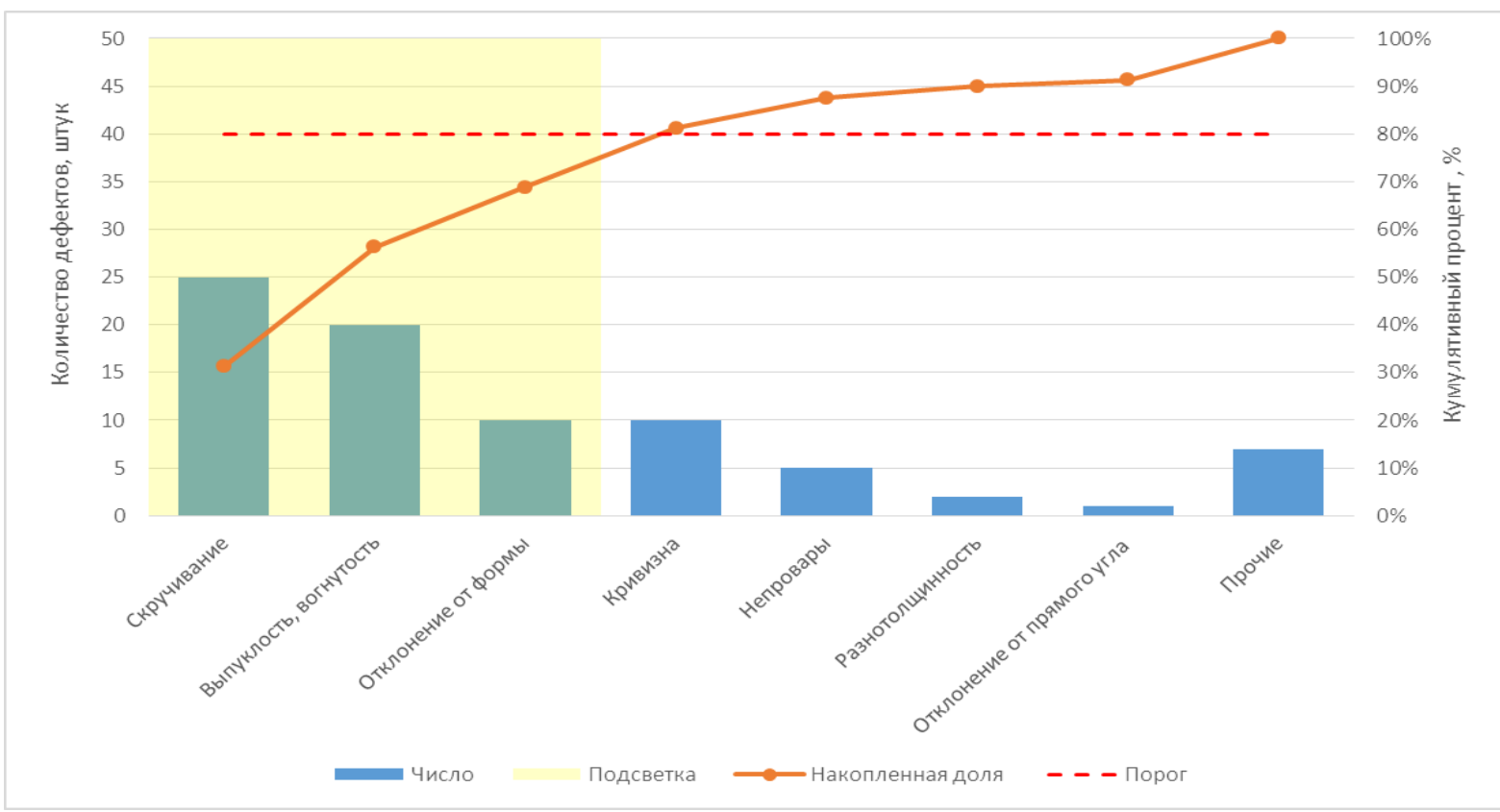

Рисунок 17 - Диаграмма Парето выявленных дефектов на «ООО «Металл Строй» за 2018 год

За 2017 год, согласно диаграмме ((рисунок 16), наиболее часто встречаемыми дефектами производимой продукции оказались скручивание, выпуклость, вогнутость, отклонение от формы и кривизна. Прочими дефектами являются риски, раковины, вздутия, царапины, трещины, пузырьки и т.д. за 2018 год выяснилось, что количество дефектной продукции сократилось, но при этом наиболее часто встречаемые дефектами остались по-прежнему скручивание, выпуклость, вогнутость, отклонение от формы и кривизна. Такие дефекты как коррозия и заусенцы полностью устранены. В результате внедрения СТО для уменьшения дефектной продукции видно, что её количество заметно снизилось.

Эффективность разработанных мероприятий в рамках СМК для повышения качества продукции подтверждена выполненными расчётами.

Другое предприятие, а именно, ООО «ДонТекс» также является современным высокоразвитым предприятием по выпуску мягких контейнеров для промышленных сыпучих грузов. Предприятие изготовляет продукцию высокого технического уровня, которая является конкурентоспособной и востребованной на внутреннем ринке России и на рынках стран СНГ.

Для решения всевозможных проблемы, связанных с появлением брака, неполадками оборудования, увеличением времени от выпуска продукции до её сбыта, наличием на складе нереализованной продукции, поступлением рекламаций применяется диаграмма Парето[1-3]

Диаграмма Парето позволяет распределить усилия для разрешения возникающих проблем и установить основные факторы, с которых нужно начинать действовать с целью преодоления возникающих проблем.

В таблицах 9 представлены данные о дефектах, выявленные за 2017 год, а в таблице 10ожидаемое число дефектов за 2018

Таблица 9 - Характеристика дефектов, выявленные на ООО «Дон - Текс» за 2017 год

\begin{tabular}{|l|l|l|l|}
\hline Дефект & Число дефектов & Накопленная доля дефектов & Кумулятивный процент \\
\hline \multicolumn{1}{|c|}{2} & \multicolumn{1}{|c|}{2} & \multicolumn{1}{c|}{3} & \multicolumn{1}{c|}{4} \\
\hline Подплетина & 100 & $12,90 \%$ & $12,90 \%$ \\
\hline Пролёт & 89 & $11,50 \%$ & $24,40 \%$ \\
\hline Вытяжка & 87 & $11 \%$ & $35,60 \%$ \\
\hline Белизна & 81 & $10,50 \%$ & $46,10 \%$ \\
\hline Массовый обрыв & 77 & $9,90 \%$ & $56 \%$ \\
\hline «Раздвижка» нитей основы & 74 & $9,60 \%$ & $65,60 \%$ \\
\hline
\end{tabular}




\begin{tabular}{|c|c|c|c|c|c|c|}
\hline \multirow{4}{*}{ Impact Factor: } & ISRA (India) & $=3.117$ & SIS (USA) & $=0.912$ & ICV (Poland) & $=6.630$ \\
\hline & ISI (Dubai, UAE & $=0.829$ & РИНЦ (Russia & $=0.156$ & PIF (India) & $=1.940$ \\
\hline & GIF (Australia) & $=0.564$ & ESJI (KZ) & $=8.716$ & IBI (India) & $=4.260$ \\
\hline & JIF & $=1.500$ & SJIF (Morocco & $=5.667$ & OAJI (USA) & $=0.350$ \\
\hline
\end{tabular}

\begin{tabular}{|l|l|l|l|}
\hline «Колючая» поверхность & 63 & $8,10 \%$ & $73,70 \%$ \\
\hline Масляные пятна & 61 & $7,90 \%$ & $81,60 \%$ \\
\hline Узлы & 43 & $5,50 \%$ & $87,10 \%$ \\
\hline Недосеки & 36 & $4,60 \%$ & $91,70 \%$ \\
\hline Осыпаемость кромки & 34 & $4,40 \%$ & $96,10 \%$ \\
\hline Прочие дефекты & 30 & $3,90 \%$ & $100 \%$ \\
\hline Итого & 775 & $100,00 \%$ & \\
\hline
\end{tabular}

На рисунке 18 представлена диаграмма Парето характеризующая дефекты выявленные на ООО «Дон-Текс» за 2017 год, а на рисунке 19 ожидаемые дефекты за 2018 год За 2018 год количество дефектной продукции сократилось, но при этом наиболее трудно устранимы дефекты подплетина и пролёты остались по-прежнему.
Как видно, за 2018 год в результате разработанных мероприятий в рамках СМК удалось уменьшить процент продукции, её количество заметно снизилось и имеет тенденцию к снижению взятого дефекта.

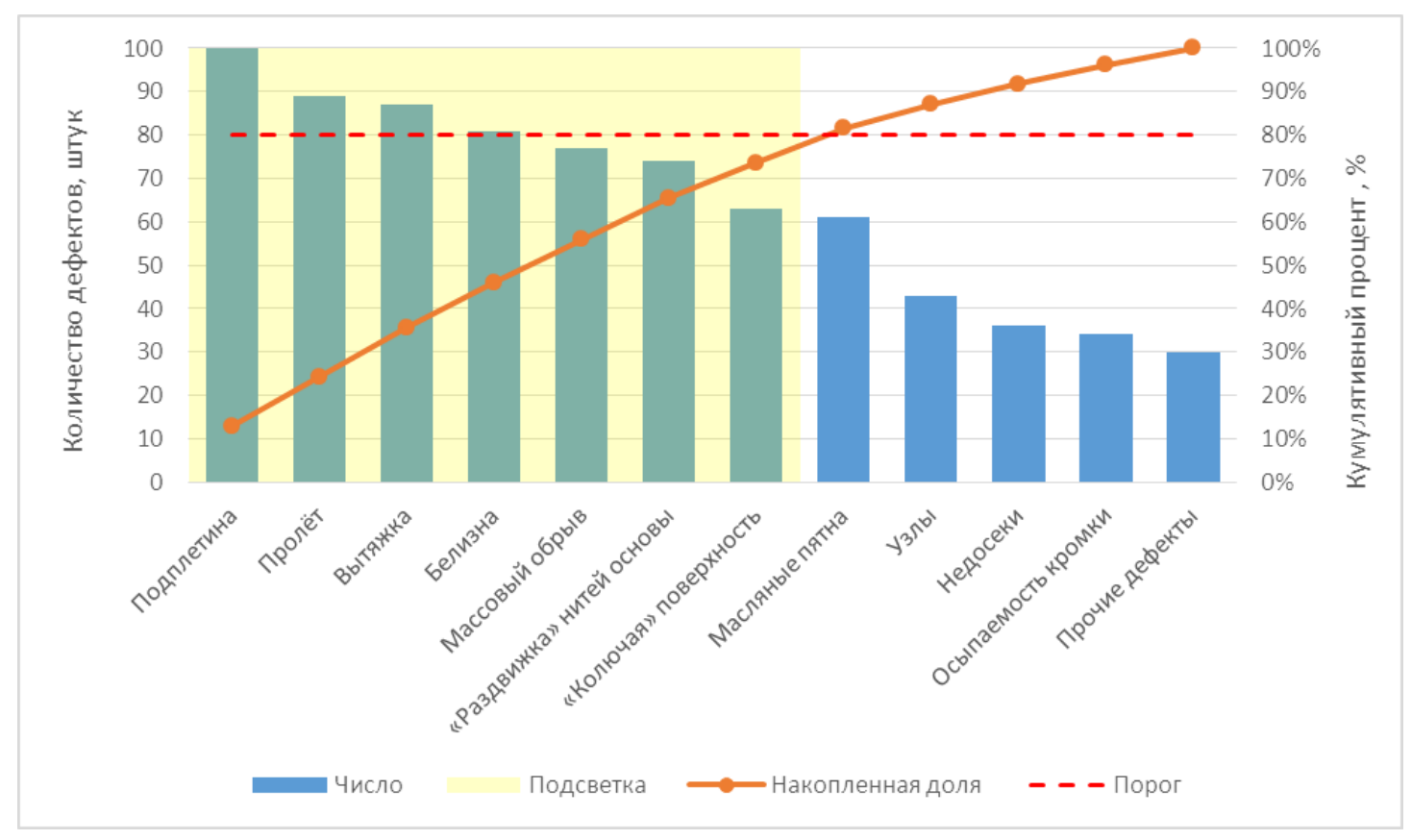

Рисунок 18 - Диаграмма Парето выявленных дефектов на ООО «Дон - Текс» за 2017год 


\begin{tabular}{|c|c|c|c|c|c|c|}
\hline \multirow{4}{*}{ Impact Factor: } & ISRA (India) & $=3.117$ & SIS (USA) & $=0.912$ & ICV (Poland) & $=6.630$ \\
\hline & ISI (Dubai, UAE & $=0.829$ & РИНЦ (Russia & $=0.156$ & PIF (India) & $=1.940$ \\
\hline & GIF (Australia) & $=0.564$ & ESJI (KZ) & $=8.716$ & IBI (India) & $=4.260$ \\
\hline & JIF & $=1.500$ & SJIF (Morocce & $=5.667$ & OAJI (USA) & $=0.350$ \\
\hline
\end{tabular}

Таблица10-Характеристика дефектов, выявленные на ООО «Дон - Текс» за 2018 год.

\begin{tabular}{|l|l|l|l|}
\hline Дефект & Число дефектов & Накопленная доля дефектов & Кумулятивный процент \\
\hline Подплетина & 37 & $16,20 \%$ & $16,20 \%$ \\
\hline Пролёт & 30 & $13,10 \%$ & $29,30 \%$ \\
\hline Вытяжка & 27 & $12 \%$ & $41,10 \%$ \\
\hline Белизна & 20 & $8,70 \%$ & $49,80 \%$ \\
\hline Массовый обрыв & 20 & $8,70 \%$ & $59 \%$ \\
\hline «Раздвижка» нитей основы & 19 & $8,30 \%$ & $66,80 \%$ \\
\hline «Колючая» поверхность & 17 & $7,40 \%$ & $74,20 \%$ \\
\hline Масляные пятна & 15 & $6,50 \%$ & $80,70 \%$ \\
\hline Узлы & 13 & $5,70 \%$ & $86,40 \%$ \\
\hline Недосеки & 12 & $5,20 \%$ & $91,60 \%$ \\
\hline Осыпаемость кромки & 10 & $4,40 \%$ & $96,00 \%$ \\
\hline Прочие дефекты & 9 & $3,90 \%$ & $100,00 \%$ \\
\hline Итого & 229 & $100,00 \%$ & \\
\hline
\end{tabular}

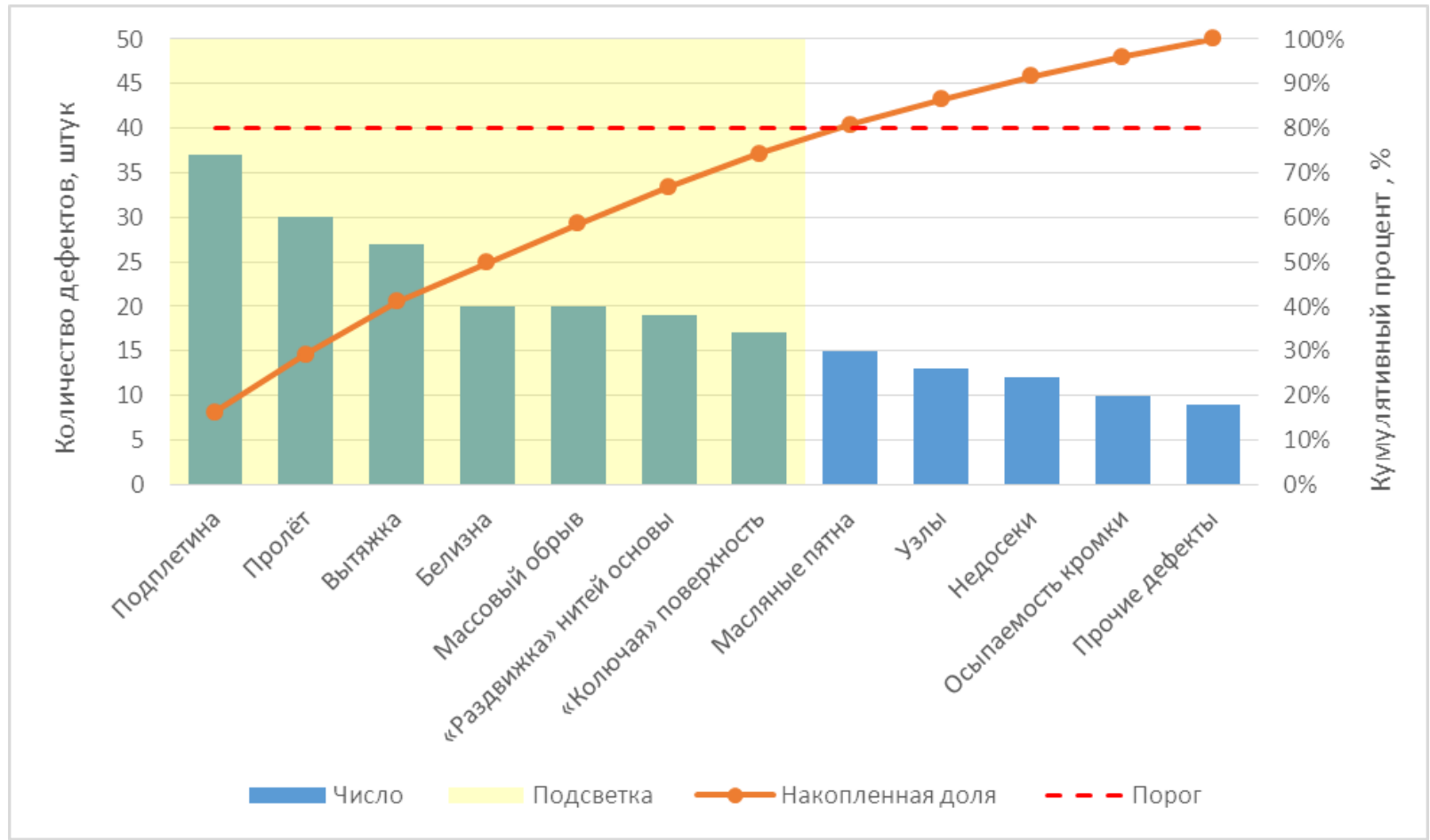

Рисунок 19 - Диаграмма Парето выявленных дефектов на ООО «Дон - Текс» за 2018год

Защита отечественных потребителей импортозамещаемой продукции от фальсифицированной и контрафактной, которую ввёл Минпромторг РФ с обязательной маркировкой средствами идентификации и мониторингу оборота импортной продукции, позволили уменьшить её долю на рынке на $10 \%$ и вернуть в бюджет РФ почти 400 млрд. руб. Но борьба за качество отечественной импортозамещаемой продукции не стала менее острой, заставляя производителей неукоснительное исполнения ими требований ГОСТов и технических регламентов. Опыт применения ими статистических методов контроля качества с использованием диаграммы Парето для реализации этих самых задач 


\begin{tabular}{|c|c|c|c|c|c|c|}
\hline \multirow{4}{*}{ Impact Factor: } & ISRA (India) & $=3.117$ & SIS (USA) & $=0.912$ & ICV (Poland) & $=6.630$ \\
\hline & ISI (Dubai, UAE & $=0.829$ & РИНЦ (Russia & $=0.156$ & PIF (India) & $=1.940$ \\
\hline & GIF (Australia) & $=0.564$ & ESJI (KZ) & $=8.716$ & IBI (India) & $=4.260$ \\
\hline & JIF & $=1.500$ & SJIF (Morocco & $=\mathbf{5 . 6 6 7}$ & OAJI (USA) & $=0.350$ \\
\hline
\end{tabular}

представлен ниже по результатам выполненных исследований.

Разработанное же авторами программное обеспечение для обработки результатов статистических методов контроля качества с использованием диаграммы Парето создаёт основу для их достоверности и гарантирует предприятиям обеспечивать своей продукцией импортозамещение.

\section{Заключение}

Преимущества партисипативного управления Популяризация партисипативного управления возникла в первую очередь за счёт объективных преимуществ, которые предоставляет подобный способ организации труда. Конечно, непосредственные достоинства данной методики могут отличаться в зависимости от используемых механизмов и особенностей каждого конкретного субъекта хозяйствования, однако ключевые аспекты будут одинаковыми во всех случаях. Так, к преимуществам партисипативного управления можно отнести повышение мотивации персонала. Работники, принимающие прямое участие в непосредственной деятельности предприятия, имеют куда более высокую мотивацию, особенно если от качества и объемов их участия зависит и их непосредственное материальное вознаграждение. Сплочение коллектива. Методы партисипативного участия напрямую демонстрируют сотрудникам важность коллективного и группового подхода к решению основных вопросов, что снижает количество конфликтов и стимулирует коллектив работать вместе над поставленными перед ним задачами. Повышение лояльности работников к предприятию. В рамках партисипативного управления работник не рассматривается только в виде обезличенного ресурса, равно как и предприятие для таких сотрудников перестает быть исключительно источником дохода, а становится ещё и результатом их прямой деятельности. Соответственно, партисипативное управление повышает лояльность сотрудников к предприятию и обеспечивает достаточное снижение текучести кадров в рамках структурного подразделения или субъекта хозяйствования в целом. Кроме этого, высокая лояльность сотрудников часто может помочь в преодолении кризисных ситуаций. Ускорение развития и внедрения инноваций. За счёт партисипативности в рамках предприятия, повышается вероятность нахождения более эффективных методов производства и организации труда, так как в вопросах поиска и внедрения инноваций участвует большое количество работников, что позволяет находить нестандартные и наиболее актуальные решения для каждого конкретного случая. Улучшение имиджа предприятия.
Партисипативное управление и соответствующее партнерское отношение к сотрудникам косвенно влияют и на внешний имидж предприятия в целом, что находит позитивное отражение практически во всех аспектах хозяйственной деятельности, начиная от упрощения поиска кадров и заканчивая повышением фактических продаж. Увеличение эффективности экономической деятельности. За счёт вышеозначенных достоинств и иных факторов, правильное применение партисипативной системы управления предприятием приводит к повышению общей экономической эффективности предприятия в большинстве случаев. Недостатки, которыми характеризуется партисипативное управление Несмотря на большое количество положительных сторон, партисипативное управление имеет и ряд определенных недостатков, что ограничивают распространение подобной бизнес-модели. Так, партисипативное управление характеризуется следующими минусами,а именно,имеет низкую эффективность в отдельных сферах деятельности. Если сфера деятельности субъекта хозяйствования предполагает, в первую очередь, использование низкоквалифицированной рабочей силы или просто монотонный и рутинный труд, без особых перспектив карьерного роста, развития или применения творческого потенциала сотрудников, то партисипативное управление будет демонстрировать отрицательную эффективность. Снижение авторитета руководства. Так как партисипативное управление предусматривает в первую очередь партнёрство, как метод субординации на работе, то в любом случае непосредственный административный авторитет руководства при применении данного способа организации труда будет снижаться. Риски злоупотреблений. Неправильное применение партисипативного управления, а также несоответствие её принципов наличествующему коллективу может привести к злоупотреблениям со стороны работников своими правами в целях простого уменьшения личной нагрузки на себя во время работы. Сложность имплементации. Далеко не всегда сотрудники могут в полной мере осознавать достоинства партисипативной системы управления именно для них, поэтому работодателю следует озаботиться о максимально подробном и длительном механизме донесения информации о преимуществах такой организации труда для сотрудников. Кроме этого, партисипативное управление также должно быть максимально подробно отражено и в кадровой документации предприятия - локальных нормативных актах, трудовых договорах и иных документах. Большинство недостатков, которыми характеризуется партисипативное управление, могут быть нивелированы при правильном 


\begin{tabular}{|c|c|c|c|c|c|c|}
\hline \multirow{4}{*}{ Impact Factor: } & ISRA (India) & $=3.117$ & SIS (USA) & $=0.912$ & ICV (Poland) & $=6.630$ \\
\hline & ISI (Dubai, UAE & $=0.829$ & РИНЦ (Russia & $=0.156$ & PIF (India) & $=1.940$ \\
\hline & GIF (Australia) & $=0.564$ & ESJI (KZ) & $=8.716$ & IBI (India) & $=4.260$ \\
\hline & JIF & $=1.500$ & SJIF (Morocco & $=\mathbf{5 . 6 6 7}$ & OAJI (USA) & $=0.350$ \\
\hline
\end{tabular}

руководстве и подходе к формированию данной системы организации труда. Однако некоторые из них являются структурными и не позволяют применять с должной эффективностью подобную методику в рамках ведения бизнеса. Поэтому, прежде чем приступать к внедрению означенной системы, следует тщательно проанализировать те преимущества и недостатки, которыми она будет обладать в рамках конкретного предприятия и конкретной сферы деятельности.

References:

1. Prokhorov, V. T., et al. (2017). The concept of import substitution of products of light industry: background, challenges, and innovations. monograph / under the General editorship of Dr. sci. prof. V. T. Prokhorova (Eds.). Institute of service and entrepreneurship (branch) of the don state technical University. (p.334). Mines: Isoip (branch) of DSTU.

2. Surovtseva, O. A., et al. (2018). Management of the real quality of products and not advertising through the motivation of the leader of the team of the enterprise of the legka industry. monograph / under the General ed. prof. V. T. Prokhorova (Eds.). Institute of service and entrepreneurship (branch) of the don state technical University. (p.384). Novocherkassk: URGU (NPI).

3. Prokhorov, V. T., et al. (2018). Competitiveness of the enterprise and competitiveness of production - guarantee of successful import substitution of the goods demanded by consumers of regions of southern Federal district and skfo. the collective monograph / under the General ed. prof. V. T. Prokhorova (Eds.). Institute of service sector and entrepreneurship (branch) of don state technical University. (p.337). Novocherkassk: Lik.

4. (2015). GOST R ISO 9000-2015 of the quality management System. The main provisions and Glossary (Amendment)

5. (2015). GOST R ISO 9001-2015 of the quality management System. The requirements of GOST R ISO 9001-2015НАЦИОНАЛЬНЫЙ STANDARD RUSSIAN FEDERATIONSTATE QUALITY MANAGEMENT date of introduction 2015-1101

6. (2016) GOST R 57189-2016/ISO/TS 9002:2016. National standard of the Russian Federation. Quality management system. Guidelines for the application of ISO 9001:2015 (ISO/TS 9002:2016, IDT)" (approved. By the order of Rosstandart on 25.10.2016 N 1499-St). [Official website of the International organization for standardization (ISO)]
Retrieved May 22, 2018, from: http://www.iso.org/iso/ru/catalogue detail?csnu mber $=52844$

7. (2010). GOST R ISO 9004-2010. Managing for the sustained success of an organization. Quality management approach.

8. Vdovin, L. P., Prokhorov, V. T., Osin, T. M., Meleshko, E. N., \& Osaca, N. I. (2014). A means of providing sustainable technical and economic indicators of the footwear enterprises in the regions of SFD and NCFD. the memory of V. A. Fokina is dedicated to: SB.nauch. articles and memories. (pp.32-41). Moscow: MSUDT. Part 3.

9. Train, Y. M., Polukhina, S. Y., Osina, T. M., Kompanchenko, E. V., \& Meleshko, E. N. (2014). About search of effective means of influence of cash flows on results of activity of the Shoe enterprises of regions of southern Federal district and skfo. Innovative development of light and textile industry" (INTEX-2014): abstracts of the all-Russian scientific student conference. (p.116). M.: FGBOU VPO "MSUDT".

10. Prokhorov, T. V., et al. (2015). The range and assortment policy. monograph / under the General editorship of Dr. sci. Sciences, Professor V. T. Prokhorov (Eds.). VoIP.

11. Prokhorov, T. V., et al. (2015). About the new features of the regions of the SFD and skfo for the formation of preferences by consumers of products manufactured at the enterprises of light industry. monograph. General ed. prof. V. T. Prokhorov (Eds.). Institute of the service sector and entrepreneurship (Phil.) Fader. state budget. educated. institutions of higher. professional education "don state technical. UN-t " in Mine Growth.region (Isoip (branch) DSTU). (p.316). Novocherkassk: URGU (NPI).

12. Prokhorov, V. T., et al. (2017). The concept of import substitution of products of light industry: background, challenges, and innovations. monograph. under the General editorship of Dr. sci. prof. V. T. Prokhorova (Eds.). Institute of service and entrepreneurship (branch) of the don 


\begin{tabular}{|c|c|c|c|c|c|c|}
\hline \multirow{4}{*}{ Impact Factor: } & ISRA (India) & $=3.117$ & SIS (USA) & $=0.912$ & ICV (Poland) & $=6.630$ \\
\hline & ISI (Dubai, UAE & $=0.829$ & РИНЦ (Russia & $=\mathbf{0 . 1 5 6}$ & PIF (India) & $=1.940$ \\
\hline & GIF (Australia) & $=0.564$ & ESJI (KZ) & $=8.716$ & IBI (India) & $=4.260$ \\
\hline & JIF & $=1.500$ & SJIF (Morocco & $=5.667$ & OAJI (USA) & $=0.350$ \\
\hline
\end{tabular}

state technical University. (p.334). Mines: Isoip (branch) DSTU.

13. Prokhorov, V. T., et al. (2014). The quality revolution: through the ad or through a quality real. monograph under the General editorship of doctor of technical Sciences, Professor V. T. Prokhorov (Eds.). VoIP (branch) of DSTU. (p.384). Novocherkassk: URGU (NPI).
14. Surovtseva, O. A., et al. (2018). Management of the real quality of products and not advertising through the motivation of the leader of the team of the enterprise of the legka industry. monograph the General ed. prof. V. T. Prokhorova (Eds.). Institute of service and entrepreneurship (branch) of the don state technical University. (p.384). Novocherkassk: URGU (NPI). 